\title{
REVIEW ARTICLE OPEN \\ Neurological heterotopic ossification: novel mechanisms, prognostic biomarkers and prophylactic therapies
}

\author{
Ker Rui Wong (iD) ${ }^{1}$, Richelle Mychasiuk ${ }^{1}$, Terence J. O'Brien ${ }^{1,2}$, Sandy R. Shultz ${ }^{1,2}$, Stuart J. McDonald ${ }^{1,3}$ and Rhys D. Brady ${ }^{1,2}$
}

Neurological heterotopic ossification (NHO) is a debilitating condition where bone forms in soft tissue, such as muscle surrounding the hip and knee, following an injury to the brain or spinal cord. This abnormal formation of bone can result in nerve impingement, pain, contractures and impaired movement. Patients are often diagnosed with $\mathrm{NHO}$ after the bone tissue has completely mineralised, leaving invasive surgical resection the only remaining treatment option. Surgical resection of NHO creates potential for added complications, particularly in patients with concomitant injury to the central nervous system (CNS). Although recent work has begun to shed light on the physiological mechanisms involved in $\mathrm{NHO}$, there remains a significant knowledge gap related to the prognostic biomarkers and prophylactic treatments which are necessary to prevent $\mathrm{NHO}$ and optimise patient outcomes. This article reviews the current understanding pertaining to NHO epidemiology, pathobiology, biomarkers and treatment options. In particular, we focus on how concomitant CNS injury may drive ectopic bone formation and discuss considerations for treating polytrauma patients with $\mathrm{NHO}$. We conclude that understanding of the pathogenesis of $\mathrm{NHO}$ is rapidly advancing, and as such, there is the strong potential for future research to unearth methods capable of identifying patients likely to develop $\mathrm{NHO}$, and targeted treatments to prevent its manifestation.

Bone Research (2020)8:42 ; https://doi.org/10.1038/s41413-020-00119-9

\section{INTRODUCTION}

Heterotopic ossification $(\mathrm{HO})$ is the pathological formation of bone in muscles and surrounding joints. The ramifications of this ectopic bone formation in soft tissue include swelling, pain, nerve entrapment, contractures, and in some cases, limited range of movement due to bone fusion in the affected area (i.e. ankylosis). ${ }^{1}$ Although various forms of hereditary and acquired $\mathrm{HO}$ exist, $\mathrm{HO}$ that occurs following a neurological insult (i.e. neurological $\mathrm{HO}$; $\mathrm{NHO}$ ) is of increasing clinical concern due to its rising prevalence in combat and civilian populations. ${ }^{2}$ Neurological heterotopic ossification (NHO) is particularly common when a neurological insult, such as a traumatic brain injury (TBI) or spinal cord injury (SCl), occurs in the presence of concomitant peripheral injuries (e.g. bone fractures, muscle injuries). Non-surgical interventions include analgesia, ${ }^{3}$ rest, ${ }^{4}$ and nerve blockers; ${ }_{i}^{5}$ however, the only cure is surgical excision. ${ }^{6,7}$ Unfortunately, invasive surgical excision can only occur once the lesion has mineralised, and reoccurs in $\sim 6 \%$ of patients. ${ }^{8}$ Consequently, there is an urgent need to develop prophylactic interventions that can prevent $\mathrm{HO}$ and are still appropriate for patients who have sustained severe trauma to the periphery and central nervous system (CNS). ${ }^{9}$ To date, the development of prophylaxes has been hindered by a limited understanding of how ectopic bone formation is triggered in response to CNS and musculoskeletal trauma. Nonetheless, there has been a recent rise in the number of clinical and pre-clinical studies designed to unearth the cellular and molecular mechanisms of NHO. This article will first review the literature regarding $\mathrm{NHO}$ epidemiology, the pathophysiology of CNS injuries, and how they may promote bone formation, mechanisms of endochondral bone formation before presenting new research avenues towards identifying novel mechanisms of $\mathrm{NHO}$, and the limited $\mathrm{NHO}$ treatment options. As the literature specific to $\mathrm{NHO}$ is relatively limited, we sometimes draw from the broader $\mathrm{HO}$ literature and make inferences where relevant.

\section{EPIDEMIOLOGY AND RISK FACTORS FOR NHO}

It has been reported that at least $10 \%-20 \%$ of patients with a TBI and simultaneous peripheral musculoskeletal injuries (i.e. polytrauma involving substantial muscle injuries and bone fractures) develop $\mathrm{NHO}^{10-13}$ Following combined $\mathrm{SCl}$ and polytrauma, $\sim 15 \%-30 \%$ of patients develop $\mathrm{NHO}^{10-12}$ This ectopic bone has a tendency to form predominantly in muscle surrounding the hip, although it also frequently affects other joints such as the knee, elbow, and shoulder (see Table 1). ${ }^{10-12}$ Notably, when $\mathrm{NHO}$ is formed posteriorly at the hip, it often entraps the sciatic nerve, resulting in neurological pain and muscle weakness, impaired movement, and difficulty performing everyday tasks (e.g. standing, sitting and getting dressed). ${ }^{10,14}$ Most studies suggest that $\mathrm{NHO}$ prevalence is significantly higher in males than females, which has been attributed to the increased number of males that experience a $\mathrm{TBI}$ or $\mathrm{SCl}^{15}$ However, a recent study employing a mouse model of $\mathrm{HO}$ (featuring a dermal burn and Achilles tenotomy) reported that male mice formed $\sim 30 \%$ more ectopic bone when compared to female mice, possibly due to increased insulin like growth factor- 1 and bone morphogenetic protein (BMP) signalling in males. ${ }^{16}$ Therefore, males may be predisposed to having increased risk for the development of $\mathrm{HO} / \mathrm{NHO}$.

Whether individuals are genetically predisposed towards $\mathrm{NHO}$ formation has not yet been established. Initial investigations have

\footnotetext{
${ }^{1}$ Department of Neuroscience, Central Clinical School, Monash University, Melbourne, VIC, Australia; ${ }^{2}$ Department of Medicine, Royal Melbourne Hospital, The University of Melbourne, Parkville, VIC, Australia and ${ }^{3}$ Department of Physiology, Anatomy and Microbiology, School of Life Sciences, La Trobe University, Bundoora, VIC, Australia Correspondence: Rhys D. Brady (rhys.brady@monash.edu)
} 
Table 1. Incidence, demographics and locations of $\mathrm{NHO}$ reported across the literature

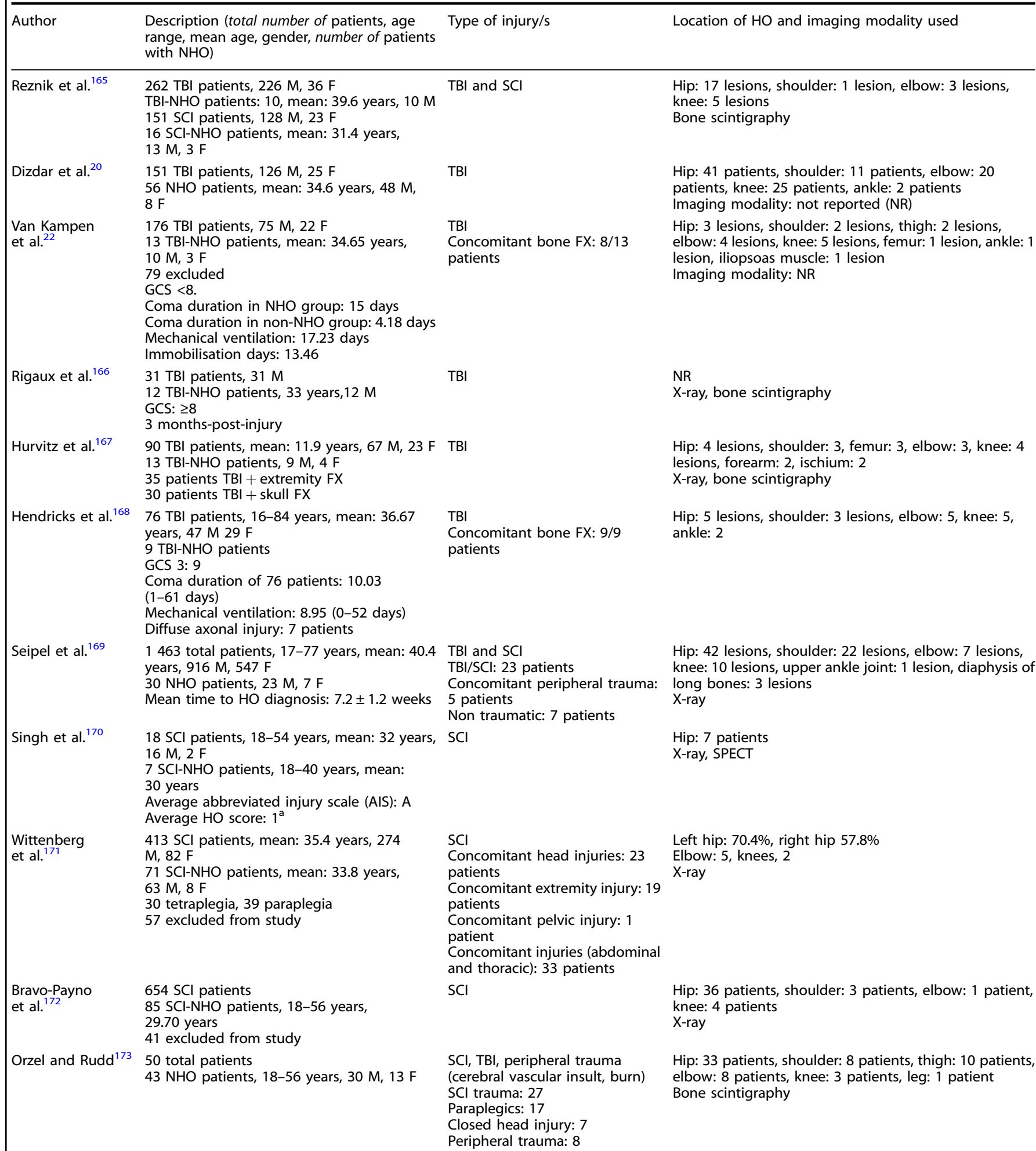

$F$ female, $M$ male, NR not reported, $T B I$ traumatic brain injury, SCI spinal cord injury, NHO neurological heterotopic ossification, $F X$ fracture, SPECT single-photon emission computed tomography

${ }^{\mathrm{a}} \mathrm{HO}$ grade according to Brooker classification

examined the association between human leukocyte antigen (HLA) serotypes and $\mathrm{NHO}$; although, there has been contradicting evidence regarding the role of HLA-B27. ${ }^{17,18}$ In a clinical study involving 43 patients with a $\mathrm{SCl}$, five of the 21 patients that developed $\mathrm{NHO}$ were positive for HLA-B27 compared to none of the 22 patients without $\mathrm{NHO} .{ }^{17}$ However, the hypothesis that HLAB27 may be a genetic risk factor for NHO was challenged by a separate study that found no differences in the frequency of any 
HLA-A and HLA-B antigens in $24 \mathrm{NHO}$ patients compared to 740 healthy controls. ${ }^{18}$ Further large-scale studies are required to determine the link between HLA antigens, and other genetically determined factors, that may contribute to $\mathrm{NHO}$.

Several risk factors have been linked to $\mathrm{NHO}$ formation, including coma duration, artificial or mechanical ventilation, duration of immobilisation, elevated serum alkaline phosphatase (ALP) levels, and the presence of TBI featuring diffuse axonal injury. ${ }^{8,19-21}$ Patients with TBI-induced $\mathrm{NHO}$ often have longer mechanical ventilation and coma duration when compared to TBI patients who do not develop $\mathrm{NHO}$; nevertheless, the exact relationship between coma duration and $\mathrm{NHO}$ formation is yet to be established. ${ }^{22}$ It has been proposed that the homoeostatic balance between calcium, oxygen, and $\mathrm{pH}$ levels are altered via artificial ventilation, which may result in respiratory alkalosis, contributing to accelerated ectopic bone formation. ${ }^{19}$ However, as increased coma duration is often the result of more severe injuries, it is difficult to determine the effect it has on NHO. These factors may contribute to the increased prevalence of $\mathrm{NHO}$ in patients following a stroke, $\mathrm{TBI}$, or $\mathrm{SCl}$.

Recent studies have identified an increased propensity to develop NHO following combat-related trauma, such as blast-TBI (bTBI) and limb amputations. ${ }^{23}$ A recent study on Iraq war operations reported that $\sim 80 \%$ of injuries were the result of explosive devices (e.g. improvised explosive devices, mortar, or mines). ${ }^{24}$ Tissue damage caused by bTBI is induced by a combination of shockwaves, supersonic flow and highly heated air flow, resulting in a string of consequences that involve thermal injury, cavitation, and increased intracranial pressure. ${ }^{25}$ An initial study examined the prevalence of $\mathrm{NHO} / \mathrm{HO}$ during the recent conflict in Iraq and Afghanistan. ${ }^{26}$ Approximately $70 \%$ of patients exposed to blast injuries requiring at least one orthopaedic procedure developed $\mathrm{HO}$, while $86 \%$ of patients who experienced a bTBI and orthopaedic procedures developed $\mathrm{NHO}^{26}$ Furthermore, univariate analysis demonstrated a significant relationship between $\mathrm{HO}$ and $\mathrm{TBI}$ severity. These findings demonstrate that the aetiology of polytrauma is incredibly heterogeneous, and as such, NHO may require several therapeutic approaches. ${ }^{27}$

\section{PATHOPHYSIOLOGY OF CNS INJURY}

$\mathrm{TBI}$ and $\mathrm{SCl}$ both induce an array of pathophysiological alterations that may stimulate either formation or resorption of bone. ${ }^{28,29}$ Briefly, acceleration-deceleration and/or rotational forces at the moment of impact can induce significant damage to neurons, glia and the vasculature, triggering a complex cascade of cellular and molecular changes that may contribute to further damage over the ensuing hours, days and months following injury. Common secondary injury mechanisms involved in $\mathrm{TBI} / \mathrm{SCl}$ can include excitotoxicity, ionic imbalances, mitochondrial dysfunction, oxidative stress, neuroinflammation, ischaemia and edema. ${ }^{30,31}$ Notably, damage to the blood-brain barrier (BBB) or blood spinal cord barrier (BSB), the semi-permeable anatomical interfaces that separate the brain and spinal cord from peripheral blood circulation, ${ }^{32}$ creates potential for abnormal passage of molecules and cells in and out of the brain and spinal cord. ${ }^{33-36}$ For example, substances that are highly concentrated in the CNS (e.g. neuropeptides) or increased following injury (e.g. inflammatory mediators, growth factors) can migrate into the peripheral circulation, and thereby potentially drive NHO formation. This notion is supported by findings that serum and CSF from TBI patients has been found to increase osteoblastic proliferation. ${ }^{37,38}$ Furthermore, prolonged pituitary dysfunction is common after $\mathrm{TBI}^{39,40}$ with alterations to the release of hormones such as parathyroid hormone ${ }^{41}$ and growth hormone, ${ }^{42}$ which may influence musculoskeletal tissues and potentially contribute to $\mathrm{NHO}$ development.

\section{CNS INJURY MAY PROMOTE BONE FORMATION}

For quite some time, orthopaedic surgeons have observed that peripheral bone fracture callus formation appears to be significantly enhanced in patients with a TBI. More recently, several clinical studies have supported this anecdotal evidence of increased callus size in TBI patients. ${ }^{43-45}$ However, human studies of this nature are often are confounded by variations in the location, nature and severity of both the bone fracture and TBI. Rodent studies that control for these variables have since demonstrated that TBI increases volume and strength of newly formed bone within the healing callus at acute and sub-acute time-points. ${ }^{46-51}$ This phenomenon may also occur following $\mathrm{SCl}$, with a recent study finding that $\mathrm{SCl}$ patients with femoral fracture had increased callus volume and accelerated rate of fracture union when compared to patients with an isolated femoral fracture. ${ }^{52}$

A preliminary study in mice has implicated the involvement of neuronal mechanisms in robust callus formation following TBI. ${ }^{53}$ It was reported that mice that received a fracture contralateral to the site of TBI had increased callus bone volume at 5 days post injury when compared to fracture-only mice, whereas callus bone volume in mice that were given a TBI ipsilateral to the fracture was comparable to fracture-only mice. ${ }^{53}$ In contrast to the aforementioned studies, ${ }^{46-51}$ these differences, however, were not observed at later time-points (i.e. 10 or 14 days post injury). ${ }^{53}$ These findings led the authors to suggest that neuronal mechanisms play a significant role in increasing bone formation acutely following TBI by causing contralateral activation of fracture healing. ${ }^{53}$ It still remains unclear as to how TBI/SCI can alter callus formation; however, it appears likely $\mathrm{TBI} / \mathrm{SCl}$-induced $\mathrm{NHO}$ share a common mechanism.

It is important to acknowledge that in the absence of a peripheral bone fracture, both $\mathrm{TBI}$ and $\mathrm{SCl}$ have been associated with reduced bone mineral density in rodents, ${ }^{54,55}$ and humans. ${ }^{29}$ These findings may indicate that cellular and molecular changes due to tissue damage (e.g. inflammation) at a peripheral site is required to stimulate $\mathrm{NHO}$ and fracture callus formation. Overall, the mechanisms responsible for the paradoxical effects that CNS injuries have on bone are yet to be elucidated.

\section{MECHANISMS OF ENDOCHONDRAL HO}

The process of ectopic bone formation in trauma induced $\mathrm{HO}$ is thought to occur via endochondral (rather than intramembranous) ossification. Although the precise mechanisms are not well characterised, a pool of osteoprogenitor cells (OPCs) residing in skeletal muscle combined with factors that are increased in response to trauma, such as inflammatory cells and molecules, enhanced BMP signalling, and hypoxia are thought to create an environment that together facilitates formation of bone by endochondral ossification. ${ }^{56,57}$ The formation of ectopic endochondral bone begins with invasion of immune cells, including neutrophils, macrophages, mast cells. ${ }^{2,57}$ The influx of inflammatory factors to the often hypoxic and acidic peripheral injury site is thought to stimulate the differentiation of OPCs to fibroblasts, which is driven by expression of fibroblast growth factors (FGFs), which form fibrous tissue. ${ }^{58-60}$ In response to hypoxia, expression of hypoxia-inducible factor- 1 alpha (HIF-a) and vascular endothelial growth factor are upregulated to stimulate angiogenesis which provides a conduit for cells to migrate to the injury site. ${ }^{61}$ Moreover, a hypoxic environment induces expression of transcription factor SOX-9, which promotes the differentiation of chondrocytes by activating SOX-9 in a HIF-1a dependent manner. ${ }^{62}$ These chondrocytes then undergo hypertrophy and begin to form a cartilaginous matrix. ${ }^{63-65}$ Subsequent remodelling of this cartilage is mediated by matrix metalloproteinases and results in the release of angiogenic factors that further promote vascular invasion. ${ }^{66}$ The cartilage is then removed as the lesion begins to mineralise. Over time the initial woven bone is then remodelled to form mature lamellar bone with a marrow cavity. Of interest, 
sources of OPCs have not yet been established, however it has been suggested that that induction of OPCs from muscle satellite cells cause HO formation. ${ }^{19,67,68}$ Other studies suggest that the source of OPCs are from fibroadipogenic progenitors that reside within the muscle interstitium, but are not exclusive to muscle. ${ }^{69}$ It is possible that identification of the exact source of these OPCs may facilitate the design of better therapeutic strategies to prevent $\mathrm{HO}$ formation. There is little information regarding whether the mechanisms of $\mathrm{NHO}$ differ from $\mathrm{HO}$, but it is important to establish as it has ramifications for identifying potential druggable targets for each condition. For example, although peripheral trauma associated $\mathrm{HO}$ is thought to occur exclusively via endochondral ossification, it is not yet known whether the additional presence of neurotrauma may alter the frequency of endochondral vs. intramembranous ossification. Additionally, an initial human study provides evidence that the histological mechanisms of ectopic bone formation were identical in lesions from $\mathrm{TBI}, \mathrm{SCl}$ and trauma induced $\mathrm{HO}^{70}$ However, significant heterogeneity existed between the location of $\mathrm{HO}$, furthermore the time-point that the $\mathrm{HO}$ was excised was not stated. Therefore, it is difficult to determine whether the mechanisms differ between $\mathrm{HO}$ and $\mathrm{NHO}$ in the acute phase, (i.e. before mineralisation). For a more in-depth description of the cellular and molecular mechanisms of $\mathrm{HO}$ formation, the reader is referred to the following reviews. ${ }^{71-75}$

\section{MECHANISMS OF HO FORMATION FOLLOWING CNS INJURY}

Current understanding of the cellular and molecular mechanisms of $\mathrm{HO}$ formation specifically in the context of neurotrauma is lacking; however, there are a number of potential mechanisms through which CNS injury may promote formation of ectopic bone at peripheral injury sites (summarised in Fig. 1). Indeed, the past decade has seen the emergence of animal models of polytrauma that have shed some light on the key drivers of $\mathrm{HO}$ formation following $\mathrm{TBI}$ or $\mathrm{SCl}$. Herein, we outline emerging evidence and hypotheses of the mechanisms of NHO formation, with a particular focus on the potential role of macrophages and neuropeptides.

Role of inflammatory cells and mediators Macrophages and neutrophils. Macrophages and neutrophils have been identified as prominent cells of the muscle inflammatory infiltrate in the acute and sub-acute phases post injury and may contribute to $\mathrm{NHO}$. Work by Genet et al. has highlighted the contribution of $\mathrm{F} 4 / 80^{+}$resident tissue macrophages as key drivers of $\mathrm{SCl}$-induced $\mathrm{NHO}^{12}$ Following $\mathrm{SCl}$ and cardiotoxin induced muscle injury, mice were injected intravenously with clodronateloaded liposomes to deplete resident tissue macrophages. ${ }^{12}$ Ablation of these resident tissue macrophages was found to reduce $\mathrm{NHO}$ volume by $\sim 90 \%$, and completely prevent $\mathrm{NHO}$ development in $3 / 11$ mice. $^{12}$ These findings indicate that macrophages likely play a prominent role in $\mathrm{SCl}$-induced $\mathrm{NHO}$ formation. Resident tissue macrophages have previously been implicated in the development of $\mathrm{HO}$, however it still remains unclear as to whether the contribution of resident tissue macrophages differs between $\mathrm{HO}$ and $\mathrm{NHO}$. To the best of our knowledge, to date no studies have compared the effect of resident tissue macrophage depletion in $\mathrm{HO}$ and $\mathrm{NHO}$ models. However, in a model of $\mathrm{HO}$ induced by burn and tenotomy, although injection of mice with clodronate-loaded liposomes decreased total $\mathrm{HO}$ volume by $\sim 50 \%, \mathrm{HO}$ was still observed in all mice. ${ }^{76}$ Although further studies are required, taken together these findings suggest that the contribution of resident tissue macrophages may differ between $\mathrm{HO}$ and $\mathrm{NHO}$.

A number of factors released by macrophages are also released by neutrophils, therefore to determine the role of neutrophils in $\mathrm{SCl}$-induced $\mathrm{NHO}$, Tseng et al. recently examined $\mathrm{NHO}$ formation in neutropenic mice. ${ }^{77}$ Neutrophil depletion had no effect on $\mathrm{NHO}$ volumes. ${ }^{77}$ Nor did treatment with rhG-CSF which significantly increased the number of neutrophils in the blood, bone marrow and injured muscles. ${ }^{77}$ These findings suggest that macrophage related factors in combination with CNS injury drive $\mathrm{NHO}$.

Oncostatin M. Oncostatin M (OSM) is an inflammatory cytokine, derived from activated macrophages, osteoclasts, monocytes, T cells, and neutrophils. ${ }^{78,79}$ OSM has been reported to stimulate osteoblastic differentiation and hence bone formation by acting on osteoclasts and osteoprogenitors. $^{80}$ The involvement of OSM in osteogenic differentiation in NHO development suggests that OSM receptor (OSMR) and OSM could be viable therapeutic targets. ${ }^{78}$

A recent study examined $\mathrm{NHO}$ formation using $\mathrm{NHO}-$ lesions from 64 patients with CNS injuries ( $\mathrm{SCl}, \mathrm{TBI}$, stroke, or cerebral anoxia) and a mouse model of $\mathrm{SCl}$-induced $\mathrm{NHO}^{78}$ Histological analysis of $\mathrm{NHO}-$ lesions excised from CNS-injured patients revealed that OSM was expressed by $\mathrm{CD}^{+} 8^{+}$macrophages and osteoclasts within $\mathrm{NHO}$ sections. ${ }^{78}$ Of note, OSM plasma protein levels were elevated twofold when compared to healthy donors (i.e. HO negative patients following total hip surgery), suggesting that plasma OSM levels may serve as a biomarker of $\mathrm{NHO}$ formation. ${ }^{78}$ It was also found that muscle-derived stromal cells isolated from $\mathrm{NHO}-l$ esions expressed OSMRs, and that treatment with recombinant human OSM increased mineralisation and differentiation. ${ }^{78}$ In addition, after $\mathrm{SCl}$-induced $\mathrm{NHO}$ in mice, immunohistochemistry and mRNA analysis demonstrated that OSM levels were significantly increased in injured muscle post-CDTX injection and $\mathrm{SCl}$, and that OSM is secreted and accumulates at the site of $\mathrm{NHO}^{78}$ Furthermore, deletion of the OSMR receptor significantly reduced $\mathrm{NHO}$ volume (median volume $14.2 \mathrm{~mm}^{3}$ in wild type, $3.2 \mathrm{~mm}^{3}$ in OSMR knockouts). Considered together, these findings suggest that OSM produced by resident tissue macrophages drives NHO formation by stimulating differentiation and mineralisation of muscle stromal cells and that OSM may represent a plasma marker and therapeutic target for preventing/ reducing $\mathrm{NHO}$ formation. ${ }^{78}$ The contribution of OSM to TBI-induced $\mathrm{NHO}$ is yet to be elucidated in a suitable model, as an animal model of TBI-induced $\mathrm{NHO}$ that accurately mimics the combinations of injuries that these patients often present with has only recently been developed. ${ }^{81}$ Briefly, this model features a concomitant femoral muscle crush injury, femoral fracture and a moderate-severe brain injury in rats, where $70 \%$ of rats that underwent these injuries developed ectopic bone at the peripheral injury site. ${ }^{81}$

\section{Role of neuropeptides}

Neuronal injury can trigger neurogenic inflammation, which in the context of moderate-severe $\mathrm{TBI}$ or $\mathrm{SCl}$ has been shown to exacerbate secondary injury pathologies such as neuronal cell death, ${ }^{82}$ BBB $^{83}$ and $\mathrm{BSB}^{82}$ oedema$^{83}$ ischaemia $^{83}$ and hypoxia. ${ }^{84}$ Neurogenic inflammation has been associated with the release of neuropeptides, particularly substance $P$ (SP) and calcitonin gene related protein (CGRP) which increases vascular permeability and vasodilation respectively. ${ }^{85}$ Impairment of the BBB following trauma can promote further propagation of neurogenic inflammatory factors, causing exacerbated neural injury. ${ }^{86}$ Notably, there is now emerging evidence that release of these neuropeptides into peripheral circulation after neurotrauma may be a key driver of $\mathrm{NHO}$ formation.

Substance P. SP is a neuropeptide that is distributed throughout the central and peripheral nervous system, with increasing evidence highlighting its role in neurogenic inflammation, bone remodelling and $\mathrm{TBI}$ pathology. ${ }^{87,88} \mathrm{SP}$ has previously been identified as a potential therapeutic target that contributes to $\mathrm{NHO}$ and $\mathrm{HO}$ development. ${ }^{12,89,90} \mathrm{SP}$ possesses a strong affinity to neurokinin-1 receptor $\left(\mathrm{NK}_{-1} \mathrm{R}\right)$ belonging to the tachykinin receptor group. ${ }^{91}$ Accumulating evidence indicates that SP contributes to $\mathrm{NHO}$ development. For instance, several human 


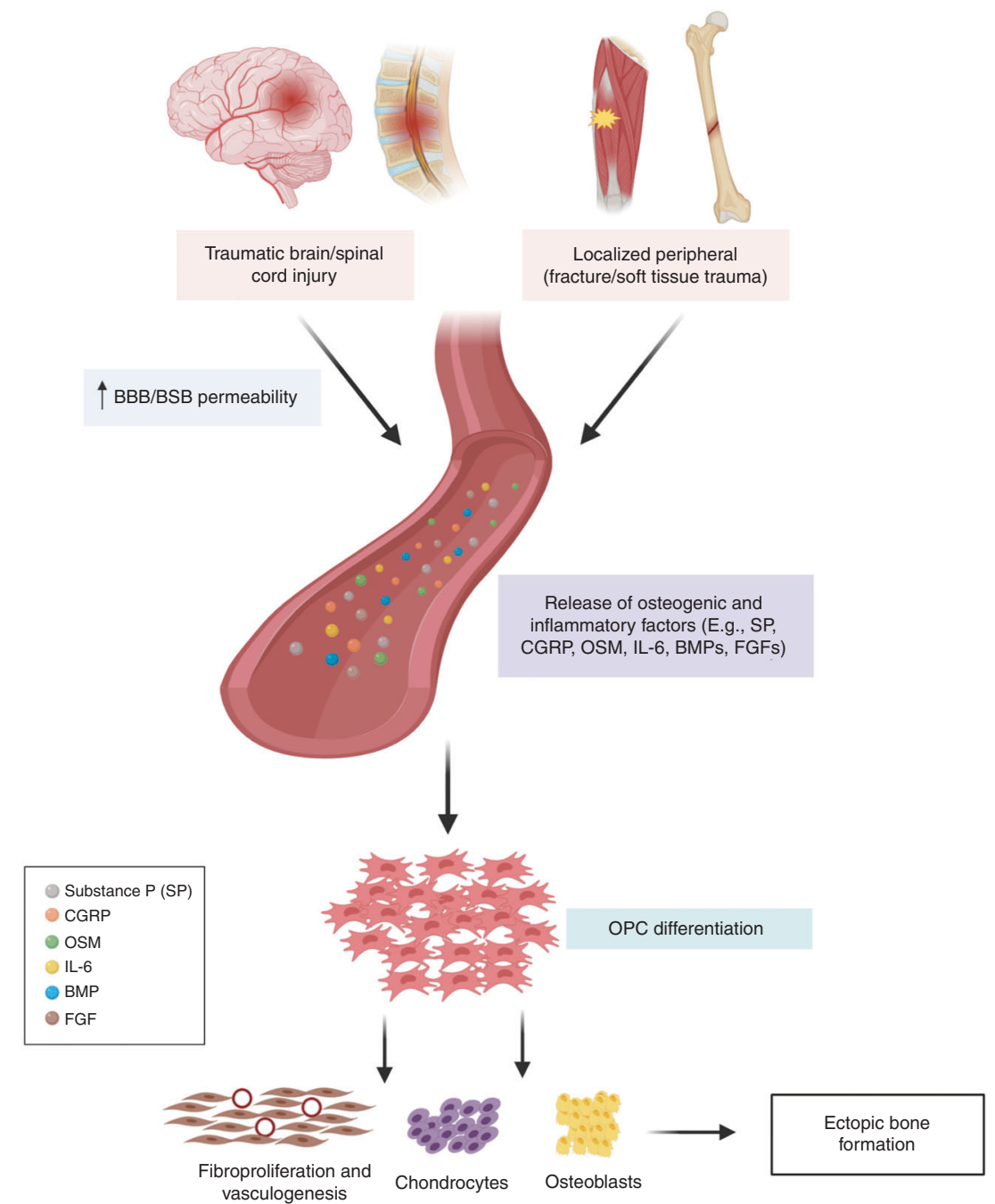

Fig. 1 Proposed mechanism for NHO development. Simultaneous injury to the CNS and peripheral sites triggers the release of osteogenic and inflammatory factors including; SP, CGRP, OSM, IL-6, BMPs and FGFs. The influx of osteogenic and inflammatory factors, initiates the differentiation of OPCs into fibroblasts which is mediated by fibroblast growth factors (FGFs). This influx also elicits angiogenesis, which results in an increase in oxygen tension, triggering the differentiation of OPCs into chondrocytes which undergo hypertrophy and form a cartilage matrix. This cartilaginous matrix provides a structural framework for the formation of blood vessels, osteoblast proliferation and differentiation and formation of ectopic bone (created with BioRender.com)

and animal studies have reported that SP levels are elevated in the blood following $\mathrm{TBI}$ and $\mathrm{SCl} .{ }^{92,93}$ Most notably, the role of SP in $\mathrm{NHO}$ has been studied in patients a murine model of SCl-induced $\mathrm{NHO} .^{12} \mathrm{SP}$ concentrations were significantly higher in plasma from $\mathrm{NHO}$ patients compared to healthy volunteers. While in the mouse model, antagonising SP receptor NK- ${ }_{1} \mathrm{R}$ with $\mathrm{RP} 67580$ reduced $\mathrm{NHO}$ volume by $\sim 30 \% .^{12}$ These findings indicate that SP may represent both a prognostic biomarker of $\mathrm{NHO}$ and a treatment target, whereby an intervention that downregulates SP is initiated following elevated plasma levels of SP.

Mast cell degranulation has been reported to be essential for SP to induce $\mathrm{HO}$ formation. ${ }^{94,95}$ Further, mast cells also release serotonin, which is known to have dual functions in bone remodelling dependent upon the site of production and it has been proposed that serotonin may drive adipocyte differentiation, creating a further hypoxic microenvironment for $\mathrm{NHO}$ formation. ${ }^{96}$ With respect to $\mathrm{TBI}$-induced $\mathrm{NHO}$, the role of SP has yet to be examined. However, the release of SP following TBI is associated with increased BBB permeability, brain oedema formation, as well as increased intracranial pressure, which contributes to neuronal cell death after the initial trauma. ${ }^{97}$ Therefore, it is likely that targeting SP may affect $\mathrm{NHO}$ either acting locally by preventing ectopic bone formation at the peripheral injury site or by acting centrally where attenuating TBI outcomes may result in reduced $\mathrm{NHO}$ volume.

Altogether, these findings propose that SP does play a significant role in both $\mathrm{NHO}$ and $\mathrm{HO}$ formation. Given the essential role of SP in acute CNS injuries, further studies need to be carried out to potentially use SP as a therapeutic target and blood-based biomarker of $\mathrm{NHO} .^{98}$

Calcitonin gene related protein (CGRP). CGRP is a sensory neuropeptide that is distributed in both the CNS ${ }^{99}$ and PNS. ${ }^{10}$ In the CNS, CGRP is expressed in cerebral cortex, hippocampus and hypothalamus, ${ }^{99}$ while in the $\mathrm{CNS}^{99}$ and PNS ${ }^{100}$ can be found in sensory, motor neurons and often colocalizes with SP. ${ }^{100}$ The upregulation of CGRP following TBI is also thought to contribute to neurogenic inflammation. ${ }^{85}$ While the precise role of CGRP in the development of $\mathrm{NHO}$ remains to be elucidated, in a mouse model of SCl-induced NHO significantly elevated levels of CGRP were found within the injured muscle 14 days post injury. ${ }^{101}$ In vitro, CGRP was found to promote the differentiation of fibroadipogenic progenitor cells to chondrocytes. ${ }^{101}$ Interestingly, studies in rodents have revealed that $\mathrm{TBI}^{102-104}$ or $\mathrm{SCl}^{104}$ 
concomitant with fracture elevates CGRP serum levels, with these animals having accelerated bone healing. This suggests that increased expression of CGRP following CNS trauma and peripheral injury may contribute to heterotopic bone formation by triggering neurogenic inflammation; however, further studies examining the relationship between SP, CGRP and $\mathrm{NHO}$ are required to determine its exact mechanism.

Other neuropeptides. Neurotrophins such as nerve growth factor (NGF), neurotrophin-3 (NT-3), neutrophin-4 (NT-4), and brain-derived neurotrophic factor have all been associated with alterations in bone metabolism. NGF is responsible for the growth and maintenance of neuronal and non-neuronal cells in both PNS and CNS. ${ }^{105}$ However, a growing body of evidence suggests that NGF and NT-3 may play a role in skeletal development, ${ }^{106}$ fracture healing ${ }^{107-109}$ and $\mathrm{HO} .{ }^{110}$ For example, in a rat model of $\mathrm{HO}$ which features bilateral midpoint Achilles tenotomy, mRNA expression of NT-3 was significantly (100-fold), while NGF levels were more modestly increased $(<20$-fold) from 4 weeks to 12 -week posttenotomy. ${ }^{110}$ The role that these neuropeptides play in $\mathrm{NHO}$ is yet to be reported in the literature.

Disrupted neural signalling

There is increasing recognition that bone modelling and remodelling can be regulated by the CNS, with hypothalamic leptin signalling being a key regulator of bone remodelling. ${ }^{111}$ Although the precise mechanisms are unclear, it has been theorised that central regulation of bone formation occurs via activation of efferent pathways relayed via the brainstem. ${ }^{11,112}$ As such, damage or alterations in excitability of these neural pathways following $\mathrm{TBI}$ or $\mathrm{SCl}$ may also be a contributor to $\mathrm{NHO}$ formation. Supporting this hypothesis, ventromedial hypothalamic neurons have been identified as playing a key role in bone formation, with chemical lesioning of these neurons resulting in a high bone mass phenotype in mice. ${ }^{113}$ This was thought to occur via ablation of leptin receptors which are densely populated in this region, thus inhibiting the osteogenic effect of leptin. ${ }^{113}$ Indeed, future studies are required to elucidate the role of efferent signalling on $\mathrm{NHO}$, as well as the effect that lesions to different structures of the brain have on TBI-induced NHO.

\section{TREATMENTS FOR NHO}

In this section, an overview of existing therapeutic interventions for $\mathrm{NHO}$ will be provided. These approaches are summarised in Fig. 2. These strategies include surgical resection of completely mineralised ectopic bone, radiotherapy, non-steroidal anti-inflammatory drugs (NSAIDs) and bisphosphonates. In addition, important considerations for these treatments in the context of polytrauma involving CNS injury are discussed.

\section{Surgical excision}

Presently, invasive surgical resection is the only effective clinical approach to cure NHO., ${ }^{6,7}$ However, it is recommended that surgery should only be considered if $\mathrm{NHO}$ patients fulfil the following criteria: (1) a significant reduction in range of motion (ROM) due to joint ankylosis, (2) an absence of acute inflammatory response and (3) the lesion is sufficiently mineralised (mature) to enable excision. ${ }^{1,114,115}$ However, several other factors are also to be considered when deciding the timing of surgical intervention. Previous studies have found that to reduce the risk of recurrence, surgical excision is preferred after ectopic bone has fully mineralised. ${ }^{10,116,117}$ Following $\mathrm{SCl}$ and $\mathrm{TBI}$, resection was traditionally performed $>12-18$ months-post injury. ${ }^{1,118}$ Over the past decade there has been a shift in the clinical management of $\mathrm{NHO}$ to favour earlier resection i.e. surgery is performed as soon as the patient is stable enough to undergo surgery and the lesion is sufficiently mineralised to enable resection. ${ }^{8,119-121}$ These changes were based on findings that earlier resection of NHO-lesions did not in fact increase the risk of recurrence. ${ }^{8,119-121}$ Further, recent evidence suggests that early excision may reduce the risk of operative complications (e.g. peri-operative fracture), enhance bone and articular cartilage health, and reduce negative cerebral changes (e.g. atrophy of motor areas) that further inhibit ROM (see Table 2). ${ }^{11,118,122}$

Resection has however been associated with a number of complications. For example, complete excision of periarticular $\mathrm{NHO}$ is particularly difficult, with patients often left with persistent decreases in ROM. Lesion remnants can result in both functional and physiological impairment due to impingement of neurovascular bundles, ankylosis, and pain. ${ }^{10,118,123-125}$ Like any other invasive procedures, post- and intra-operative $\mathrm{NHO}$ excision is associated with potential blood loss and

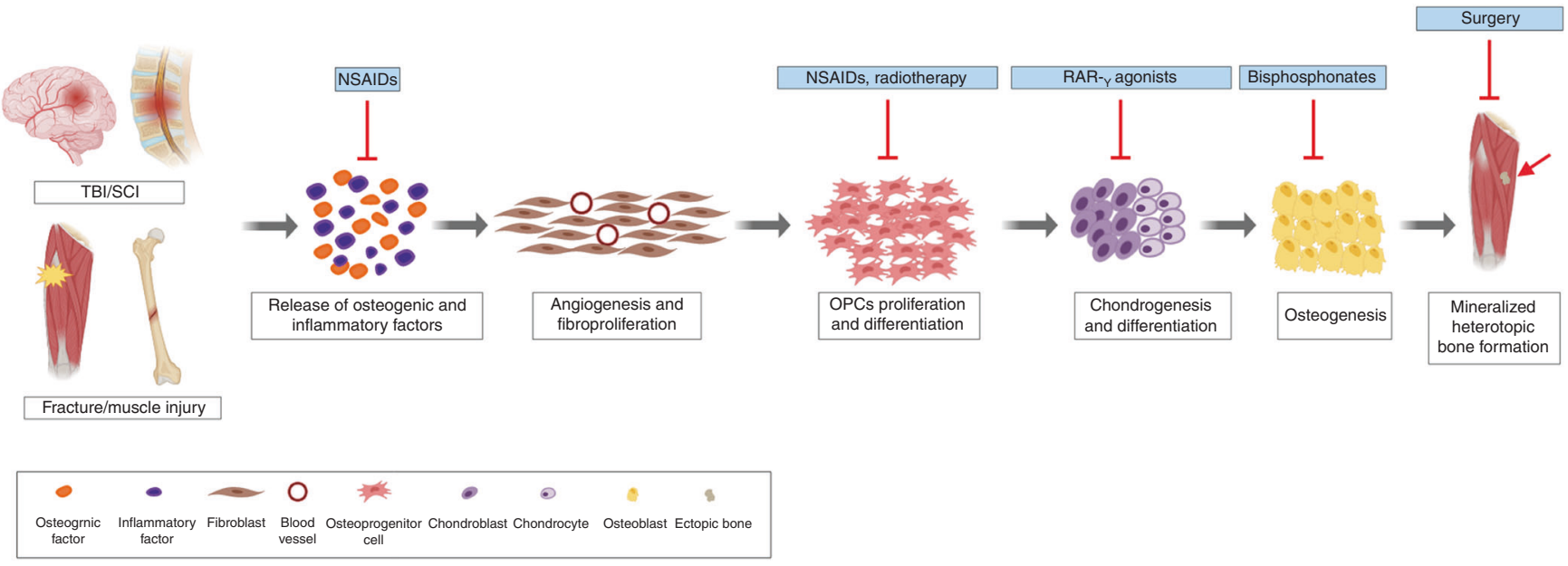

Fig. 2 Current treatments targeting specific pathways of NHO. NHO development is triggered by a cascade of inflammatory factors. Presently, the preferred prophylactic treatment for NHO/HO involves NSAIDs (e.g. Indomethacin) to downregulate the inflammatory response and prevent OPC differentiation. Radiotherapy is thought to prevent the formation and development of ectopic bone specifically by inhibiting the differentiation of OPCs. RAR- $\gamma$ agonists have been shown to prevent chondrogenesis and therefore subsequent mineralisation. While, nitrogen-containing bisphosphonates (e.g. sodium etidronate) have been used to inhibit mineralisation, and the formation of ectopic bone. Finally, when bone is completely mineralised, surgical resection is the only remaining intervention. This invasive procedure, however, is accompanied by the risk of recurrence and is associated with complications which include incomplete resection, functional and physiological impairment (created with BioRender.com) 
Table 2. Treatments for clinical and radiographical evidence of HO/NHO reported across literature

$\begin{array}{lll}\text { Author Description (total number of patients, Injury and imaging } & \text { Location of NHO and treatment/s } \\ \text { age range, mean age, gender, } & \text { modality used to }\end{array}$
$\begin{array}{ll}\text { age range, mean age, gender, } & \text { modality used to } \\ \text { number of patients with } \mathrm{NHO}) & \text { confirm } \mathrm{NHO}\end{array}$

Reported recurrence and complications

\section{Surgical resection \\ Meiners $29 \mathrm{SCl}-\mathrm{NHO}$ patients, 27-68.13 years, $\mathrm{SCl}$ \\ et al. ${ }^{174}$ mean: 37.87 years, $28 \mathrm{M}, 1 \mathrm{~F}$ X-ray \\ 41 lesions \\ Cervical lesions of spinal cord: 10 \\ patients \\ Thoracic spine lesions: 19 patients}

\begin{tabular}{|c|c|}
\hline $\begin{array}{l}\text { Hunt } \\
\text { et al. }{ }^{175}\end{array}$ & $\begin{array}{l}42 \text { burns patients, } 22-62 \text { years, mea } \\
38 \text { years } \\
42 \text { burn-HO patients, } 22-62 \text { years, } \\
\text { mean: } 38 \text { years } \\
47 \text { lesions } \\
\text { Mean TBSA: } 55 \% \\
\text { Mean third degree burn: } 37 \% \\
\text { Average ventilator support: } 58 \text { day }\end{array}$ \\
\hline \multicolumn{2}{|c|}{ Radiation therapy } \\
\hline $\begin{array}{l}\text { Hamid } \\
\text { et al. }{ }^{134}\end{array}$ & $\begin{array}{l}45 \text { patients with elbow trauma, } \\
18-65 \text { years, mean: } 44 \text { years, } 25 \\
\text { M, } 20 \mathrm{~F} \\
20 \text { elbow trauma-HO patients }\end{array}$ \\
\hline
\end{tabular}

Stein

et al. ${ }^{176}$

11 patients with elbow trauma,

28-78 years, mean: 51 years, $3 \mathrm{M}, 8 \mathrm{~F}$ the elbow

3 elbow trauma-HO patients, 54-78, Radiographs

mean: 63 years, $1 \mathrm{M}, 2 \mathrm{~F}$

3 lesions

\section{Müseler $244 \mathrm{SCl}-\mathrm{NHO}$ patients, 18-81 years, et al. $^{17}$ \\ mean: 46.4 years, $207 \mathrm{M}, 37 \mathrm{~F}$ \\ 444 lesions \\ AIS A-12 patients ( 4 tetraplegic 8 \\ paraplegic) \\ AIS B-1 patient (1 tetraplegic) \\ $60 \mathrm{NHO}$-patients, mean: 36.7 years, $47 \mathrm{M}, 13 \mathrm{~F}$}

72 lesions

Burn injuries

X-ray

Intraarticular dista

humeral fracture,

Fracture-dislocation with proximal radial and/or ulnar fracture $\mathrm{X}$-ray, CT scan
Hip

Dose: average: $9.17 \mathrm{~Gy}$, range: $0.7-12 \mathrm{~Gy}$ in $1-5$ sessions

Mean follow-up: 4.2 years

Mean time to surgery: 82.1 months

(17-298 months)

Indications for surgery: seating problems,

loss of functions, pressure sore, pain

Preoperative ROM: $21.95^{\circ}$ (range: $0-80^{\circ}$ )

Postoperative ROM: $82.68^{\circ}$ (range:

$0-120^{\circ}$ )

Hip, elbow, forearm

Indications for surgery: decreased ROM resulting in loss of functions in daily activities, ulnar nerve entrapment,

inability to perform physical therapy

Preoperative ROM: $52^{\circ}$

Postoperative ROM: $119^{\circ}$

Elbow

Dose: 700 cGy single fraction dose at 6-

MeV photons), $N=21$

Mean follow-up: 7.5 months (range:

6-26 months)

Mean time to treatment: $72 \mathrm{~h}$

Indications for treatment: seating

problems, loss of functions, decubitus,

pressure sore, pain

Preoperative ROM: $21.95^{\circ}$ (range: $0-80^{\circ}$ )

Postoperative ROM: $82.68^{\circ}$ (range:

$0-120^{\circ}$ )

\section{1 patients}

Dose: 700 cGy single non-fractionated at unreported $\mathrm{MeV}$

Mean follow-up: 12 months (range:

9-24 months)

Mean time to treatment: 5 days (range:

$0-16$ days)

Indications for treatment: NR

Preoperative ROM: NR

Postoperative ROM: $114.5^{\circ}$ (range:

0-135 )

Radiation therapy (7 Gy, single dose

accompanied by $15 \mathrm{MV}$ or $6 \mathrm{MV}$ )

Mean follow-up: 89.4 days

Mean time to treatment: 3.7 days

Indications for treatment: NR

\section{0 patients}

Dose: 700 cGy dose of radiation

Mean follow-up: 12.7 months (range:

6-33 months)

Mean time to treatment: 1.18 days (range: 0-4 days)

Indications for treatment: limited ROM,

nerve impingement, reduced quality of

life and functions

Preoperative ROM: Postoperative ROM:

Hip-4.23 ${ }^{\circ}$, Hip-67. $2^{\circ}$

Knees-81.3, Knees-117.5

Elbows-4.0 $0^{\circ}$, Elbows- $140.0^{\circ}$

NSAIDs

Banovac et al. $^{138}$

$33 \mathrm{SCl}-\mathrm{NHO}$ patients

AIS A-13 (5 tetraplegics, 7

paraplegic)

AIS B-1 (1 tetraplegic)

AIS C-2 (2 paraplegic)

AIS D-1 (1 tetraplegic)
$\mathrm{SCl}$

Bone scintigraphy

(early stage)

X-ray (later stage)

\section{6 patients \\ 16 patients}

disodium etidronate, $300 \mathrm{mg}$ daily for

3 days, oral etidronate, $20 \mathrm{mg} \cdot \mathrm{kg}^{-1}$

per day for 6 months

Mean follow-up: 1.5 months

Mean time to treatment: 21 days

Indications for treatment: local erythema,

swelling, loss of joint ROM and fever
Recurrence: 3 patients

Complications: deep and superficial wound infections, fracture, aneurysm and pressure ulcer

Recurrence in 6 elbows, 1 hip and 1 forearm

Complications: ulnar nerve deficit, numbness weakness, small

haematoma, minor wound dehiscence and cellulitis.

Trial was terminated early due to high non-union rate observed in the radiation treatment group

Recurrence: 0

Complications: infection (2), nonunion (8)

Recurrence: 0

Complications: decreased sensation along ulnar nerve

Recurrence: 13 patients (26 joints) Complications: NR

Recurrence: 6 joints

Complications: NR

Recurrence in 2 patients

Complications: upper abdomina discomfort 
Table 2. continued

\begin{tabular}{|c|c|c|c|c|}
\hline Author & $\begin{array}{l}\text { Description (total number of patients, } \\
\text { age range, mean age, gender, } \\
\text { number of patients with NHO) }\end{array}$ & $\begin{array}{l}\text { Injury and imaging } \\
\text { modality used to } \\
\text { confirm NHO }\end{array}$ & Location of $\mathrm{NHO}$ and treatment/s & Reported recurrence and complications \\
\hline $\begin{array}{l}\text { Banovac } \\
\text { et al. }{ }^{179}\end{array}$ & $\begin{array}{l}76 \mathrm{SCl} \text { patients, } 65 \mathrm{M}, 11 \mathrm{~F} \\
\text { AIS } \mathrm{A}-28 \text { patients } \\
\text { AIS B-8 patients } \\
\text { AIS } \mathrm{C}-1 \text { patient }\end{array}$ & $\begin{array}{l}\mathrm{SCl} \\
\text { Bone scintigraphy, } \\
\text { radiograph }\end{array}$ & $\begin{array}{l}37 \text { patients } \\
\text { Oral rofecoxib } 25 \mathrm{mg} \text { daily, IV disodium } \\
\text { etidronate } 300 \mathrm{mg} \text { daily for } 3 \text { days, oral } \\
\text { etidronate, } 20 \mathrm{mg} \cdot \mathrm{kg}^{-1} \text { per day for } \\
6 \text { months } \\
\text { Mean time to treatment: } 25 \text { days } \\
\text { Indications for treatment: local oedema, } \\
\text { fever and decreased joint ROM }\end{array}$ & $\begin{array}{l}\text { Recurrence in } 5 / 37 \text { patients } \\
\text { Complications: NR }\end{array}$ \\
\hline $\begin{array}{l}\text { Romano } \\
\text { et al. }{ }^{180}\end{array}$ & $\begin{array}{l}400 \text { THA patients, mean: } 61.2 \text { years } \\
24 \text { excluded (due to side effects) }\end{array}$ & $\begin{array}{l}\text { Coxarthrosis, femoral } \\
\text { head necrosis } \\
\text { Radiograph }\end{array}$ & $\begin{array}{l}250 \text { patients } \\
\text { Rectal indomethacin } 50 \text { mg daily for } \\
2 \text { days, a day post-surgery followed by } \\
\text { oral indomethacin } 50 \text { mg daily for } \\
18 \text { days } \\
150 \text { patients } \\
\text { Celecoxib } 200 \text { mg daily for } 2 \text { days, } \\
\text { starting } 2 \text { days post-surgery for } 20 \text { days } \\
\text { Mean follow-up: } 12 \text { months } \\
\text { Mean time to treatment: } 1 \text { and } 2 \text { days } \\
\text { respectively }\end{array}$ & $\begin{array}{l}\text { Indomethacin: } 40 \text { patients, Celecoxib: } \\
21 \text { patients } \\
\text { Complications: (Indomethacin) } \\
\text { gastrointestinal side effects, excessive } \\
\text { bleeding, mental confusion (Celecoxib), } \\
\text { nausea and gastrointestinal pyrosis }\end{array}$ \\
\hline $\begin{array}{l}\text { Schmidt } \\
\text { et al. }\end{array}$ & $\begin{array}{l}201 \text { THA patients, } 28-89 \text {, mean: } \\
67.5 \text { years }\end{array}$ & $\begin{array}{l}\text { Total hip replacement } \\
\text { Radiograph }\end{array}$ & $\begin{array}{l}102 \text { patients } \\
\text { Oral indomethacin } 25 \mathrm{mg} \text {, thrice daily, for } \\
6 \text { weeks, starting on first } \\
\text { postoperative day } \\
\text { Mean follow-up: } 12 \text { days } \\
\text { Mean time to treatment: } 1 \text { day }\end{array}$ & $\begin{array}{l}\text { Recurrence in } 13 \text { patients } \\
\text { Complications: NR }\end{array}$ \\
\hline $\begin{array}{l}\text { Bedi } \\
\text { et al. }\end{array}$ & $\begin{array}{l}616 \text { patients after hip arthroscopy, } \\
\text { mean: } 31.3 \text { years, } 342 \mathrm{M}, 274 \mathrm{~F} \\
29 \mathrm{HO} \text { patients, } 15-57 \text { years, mean: } \\
30.6 \text { years, } 21 \mathrm{M}, 8 \mathrm{~F}\end{array}$ & $\begin{array}{l}\text { Hip arthroscopy } \\
\text { Radiographs, CT scan }\end{array}$ & $\begin{array}{l}277 \text { patients } \\
\text { Naproxen ( } 500 \mathrm{mg} \text {, twice daily for } \\
30 \text { days, starting a day post-surgery) } \\
339 \text { patients } \\
\text { Indomethacin } 75 \mathrm{mg} \text { daily for } 4 \text { days, } \\
\text { Naproxen } 500 \mathrm{mg} \text {, twice daily for } 30 \text { days } \\
\text { Mean follow-up: } 13.2 \text { months (range: } \\
2.9-16.5 \text { months) } \\
\text { Mean time to treatment: } 1 \text { day } \\
7 \text { patients } \\
\text { HO surgical excision, radiation therapy } \\
700 \text { cGy, single dose } \\
\text { Mean time to treatment: } 11.6 \text { months } \\
\text { (range: } 5.2-16.2 \text { months) }\end{array}$ & $\begin{array}{l}\text { Naproxen only: } 23 \text { patients have } \mathrm{HO} \\
\text { Naproxen + Indomethacin: } 6 \text { patients } \\
\text { Complications: NR }\end{array}$ \\
\hline $\begin{array}{l}\text { Beckmann } \\
\text { et al. }\end{array}$ & $\begin{array}{l}106 \text { patients after hip arthroscopy, } \\
\text { mean: } 35 \text { years, } 40 \mathrm{M}, 66 \mathrm{~F} \\
\text { Excluded from study: } n=10\end{array}$ & $\begin{array}{l}\text { Hip arthroscopy } \\
\text { Radiographs }\end{array}$ & $\begin{array}{l}52 \text { patients } \\
\text { Naproxen } 500 \text { mg, twice daily for } \\
3 \text { weeks, post-surgery } \\
\text { Mean time to treatment: } 1 \text { day } \\
\text { Indications for treatment: pain, } \\
\text { radiographic abnormalities and evidence } \\
\text { of labral tear on MRI }\end{array}$ & $\begin{array}{l}\text { Recurrence: } 2 \\
\text { Complications: Gastrointestinal } \\
\text { discomfort, rash, blood clot, heartburn, } \\
\text { headache and pain }\end{array}$ \\
\hline $\begin{array}{l}\text { Neal } \\
\text { et al. }\end{array}$ & $\begin{array}{l}2649 \text { THA patients, mean: } 65.5 \text { years, } \\
1311 \mathrm{M}, 1338 \mathrm{~F} \\
601 \text { excluded } \\
627 \text { lesions }\end{array}$ & $\begin{array}{l}\text { Hip arthroplasty } \\
\text { Radiograph }\end{array}$ & $\begin{array}{l}1039 \text { patients } \\
\text { Aspirin } 162 \mathrm{mg} \cdot \mathrm{d}^{-1} \text { for } 35 \text { days post- } \\
\text { surgery } \\
\text { Mean follow-up: } 22 \text { months }\end{array}$ & $\begin{array}{l}\text { Recurrence: } 627 \text { patients } \\
\text { Complications: hip pain (with the need } \\
\text { for analgesia), difficulty or restriction of } \\
\text { mobility }\end{array}$ \\
\hline \multicolumn{5}{|c|}{ Bisphosphonates } \\
\hline $\begin{array}{l}\text { Schuetz } \\
\text { et al. }\end{array}$ & $\begin{array}{l}7 \text { patients in total, } 47-68 \text { years, } \\
\text { mean: } 54.8 \text { years, } 7 \mathrm{M} \\
5 \text { patients with HO, } 47-68 \text { years, } \\
\text { mean: } 54.8 \text { years, } 5 \mathrm{M} \\
\text { Number of lesions: } 8\end{array}$ & $\begin{array}{l}\text { Caisson disease, } \\
\text { tetraplegia, e.coli } \\
\text { sepsis, } \\
\text { osteoarthritis, FOP } \\
\text { Radiographs }\end{array}$ & $\begin{array}{l}\text { IV pamidronate } 680 \mathrm{mg} / 850 \mathrm{mg} / 1200 \mathrm{mg} \\
\text { Mean follow-up: } 19.6 \text { months (range: } \\
4-54 \text { months) } \\
\text { Indications for treatment: pain, } \\
\text { hardening at operation site and } \\
\text { decreased ROM }\end{array}$ & $\begin{array}{l}\text { Recurrence in } 1 \text { patient } \\
\text { Complications: need for pain } \\
\text { medication, lower back pain }\end{array}$ \\
\hline $\begin{array}{l}\text { Orzel and } \\
\text { Rudd }^{173}\end{array}$ & $\begin{array}{l}50 \text { patients } \\
43 \text { NHO patients, } 18-56 \text { years, } 30 \\
\text { M, } 13 \mathrm{~F} \\
81 \text { lesions }\end{array}$ & $\begin{array}{l}\mathrm{SCl} \text { paraplegia, closed } \\
\text { head injury, peripheral } \\
\text { trauma, cerebral } \\
\text { vascular insult, burn } \\
\text { Bone scintigraphy }\end{array}$ & $\begin{array}{l}14 \text { patients } \\
\text { Oral etidronate disodium } 20 \mathrm{mg} \cdot \mathrm{kg}^{-1} \text { for } \\
\text { first } 2 \text { weeks followed by } 10 \mathrm{mg} \cdot \mathrm{kg}^{-1} \text { for } \\
\text { remainder of study } \\
\text { Mean follow-up: } 22.5 \text { months } \\
\text { Indications for treatment: Radiograph } \\
\text { evidence }\end{array}$ & $\begin{array}{l}\text { No response to therapy in } 4 / 14 \\
\text { Complications: NR }\end{array}$ \\
\hline Banovac ${ }^{154}$ & $\begin{array}{l}40 \mathrm{SCl}-\mathrm{NHO} \text { patients, mean: } 23 \text { years, } \\
39 \mathrm{M}, 1 \mathrm{~F} \\
\text { AIS } \mathrm{A}-37 \text { patients ( } 16 \text { are } \\
\text { tetraplegic, } 21 \text { are paraplegic) } \\
\text { AIS B-3 patients ( } 2 \text { are tetraplegic, } 1 \\
\text { is paraplegic) }\end{array}$ & $\begin{array}{l}\mathrm{SCl} \\
\text { Radiograph and bone } \\
\text { scintigraphy }\end{array}$ & $\begin{array}{l}40 \text { patients } \\
\text { IV etidronate sodium } 300 \mathrm{mg}, 3 \text { doses for } \\
3 \text { days followed by oral etidronate } \\
\text { sodium } 20 \mathrm{mg} \cdot \mathrm{kg}^{-1} \text { per day for } 6 \text { months } \\
\text { Mean follow-up: } 35 \text { months } \\
\text { Indications for treatment: oedema, } \\
\text { reduced ROM, fever, positive scintigraphy }\end{array}$ & $\begin{array}{l}\text { Recurrence in } 2 \text { patients, } \\
\text { Complications: NR }\end{array}$ \\
\hline $\begin{array}{l}\text { Banovac } \\
\text { et al. }{ }^{152}\end{array}$ & $\begin{array}{l}27 \mathrm{SCl} \text { patients, } 16-54 \text { years, mean: } \\
36 \text { years, } 25 \mathrm{M}, 2 \mathrm{~F}\end{array}$ & $\begin{array}{l}\mathrm{SCl} \\
\text { Bone scintigraphy }\end{array}$ & $\begin{array}{l}24 \text { patients } \\
\text { IV etidronate disodium ( } 300 \mathrm{mg} \text { for } 3 \mathrm{~h}, 3 \\
\text { doses for } 3 \text { days } / 5 \text { days) followed by oral }\end{array}$ & Recurrence: 11 patients \\
\hline
\end{tabular}




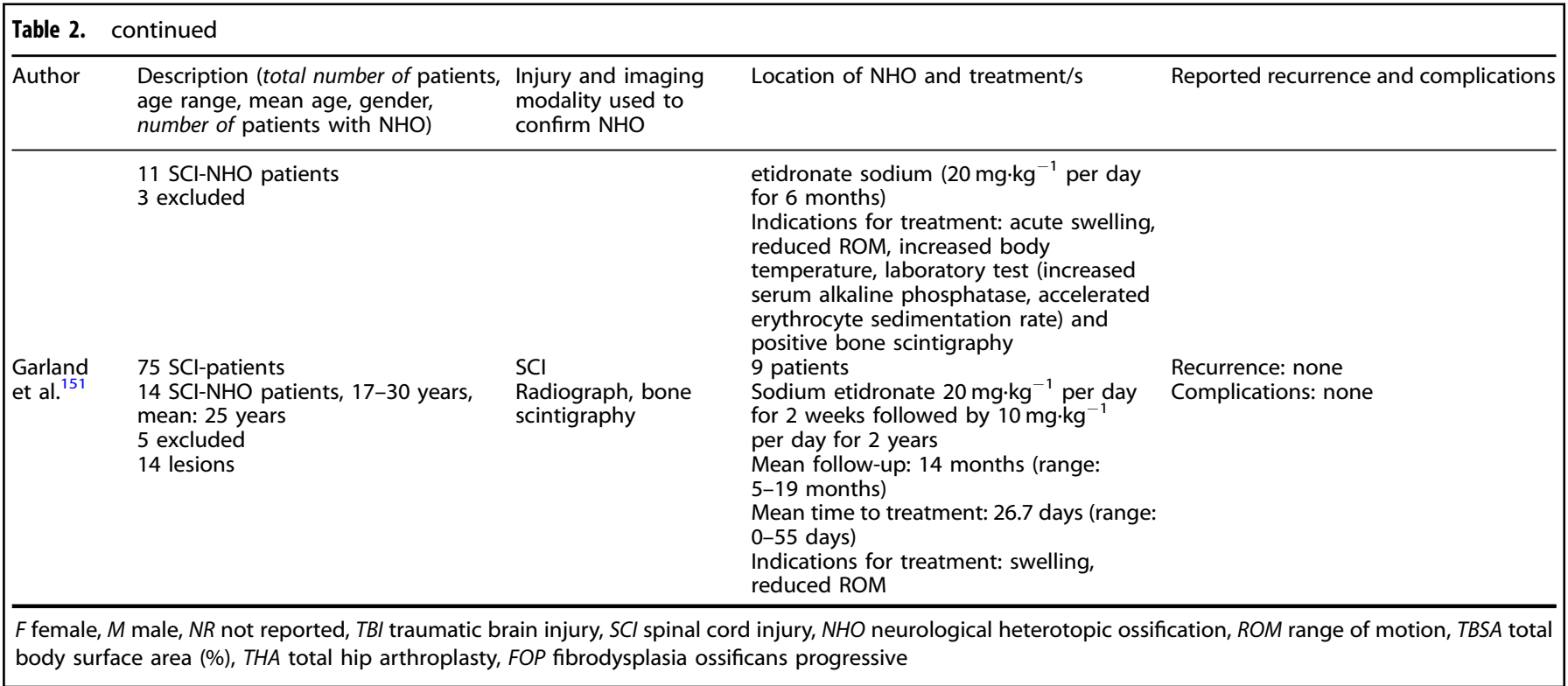

infection-both complications that may have a substantial effect on TBI or $\mathrm{SCl}$ recovery. Moreover, surgical removal can damage adjacent peripheral tissues, and recurrence at the site of excision is common. ${ }^{123,126-129}$ As such, surgical intervention is not an optimal $\mathrm{NHO}$ therapy and should be carefully considered.

Radiation therapy

Radiation therapy is thought to prevent the formation and/or progression of $\mathrm{HO}$ by inhibiting the differentiation of OPCs. ${ }^{114}$ Specifically, in vitro studies have demonstrated that radiotherapy inhibits BMP-2 signalling, reduces osteoblastic proliferation and differentiation, and promotes apoptosis. ${ }^{130,131}$ In an initial preclinical study, adult rats implanted with de-mineralised bone matrix were administered radiation at 2-, 4-, 6-, 8-, 10- and 12 days post-implantation. ${ }^{132}$ Implanted rats went on to form ectopic bone at 11 days post-implantation. ${ }^{132}$ It was noted that rats that underwent radiation at 2 - or 4 days post-implantation had reduced $\mathrm{HO}$ volume by $\sim 60 \%$ and $24 \%$ respectively. However, when radiation was delayed until 8 days post-implantation, the authors observed no difference in $\mathrm{HO}$ volume between rats that were irradiated and controls. ${ }^{132}$ Several studies have reported beneficial effects of administering radiotherapy to prevent $\mathrm{NHO}$ post-TBI and $\mathrm{SCl}$, or to prevent the recurrence of $\mathrm{NHO}$ (i.e. postexcision; see Table 2). ${ }^{133-135}$ For example, in a phase I/II clinical study, $33 \mathrm{SCl}$ patients that underwent radiotherapy observed no further ectopic bone growth, however joint mobility was mildly affected in three patients. ${ }^{133}$ In some cases, the risk of impaired fracture healing can be prevented in radiotherapy by adequately shielding the surrounding areas of interest; however, this can be difficult when ectopic bone forms close to fractures and around amputation sites. In one particular clinical study where patients with elbow injuries underwent radiation therapy, eight of the 21 patients experienced fracture non-union, whereas for the 24 patients that did not undergo radiotherapy, only one experienced non-union. ${ }^{134}$ In addition to fracture healing, radiation therapy can also disrupt wound healing, and has been associated with an increased risk of malignancy. ${ }^{136}$ Therefore, the use of radiotherapy in polytrauma NHO patients is often contraindicated. ${ }^{137}$

Non-steroidal anti-inflammatory drugs (NSAIDs)

NSAIDs have been successfully used to prevent ectopic bone formation following $\mathrm{SCl}$ and hip arthroplasty (see Table 2). While NSAIDs such as celecoxib and meloxicam have been used to prevent NHO, indomethacin, a non-selective COX-1 and COX-2 inhibitor, is currently considered the gold standard for preventing $\mathrm{NHO}$ formation and progression. ${ }^{18,138}$ The effect of indomethacin has been demonstrated in a rat model of $\mathrm{HO}$ that features subcutaneous implantation of de-mineralised bone matrix. ${ }^{139}$ When indomethacin was administered $6 \mathrm{~h}$ prior to the implantation, there was a reduction in area of ectopic bone, ALP activity, and calcium content when compared to controls. ${ }^{139}$ However, when indomethacin was administered at the time of demineralised matrix implantation or post-implantation $(6 \mathrm{~h}, 1 \mathrm{~d}$, $2 \mathrm{~d}, 3 \mathrm{~d}$, and $4 \mathrm{~d}$ ), there were no differences in ectopic bone area, ALP activity, and calcium content when compared to controls. ${ }^{139}$

Despite the proven efficacy of NSAIDs for treating NHO, it is important to recognise that there are reports of potentially negative adverse effects of these agents on patients with polytrauma. For example, rofecoxib, a highly selective COX-2 inhibitor was frequently prescribed to prevent $\mathrm{HO}^{140}$ However, it was withdrawn from the market following a randomised, placebo-controlled, double-blind clinical trial that found chronic use elevated the risk of serious cardiovascular events (i.e. heart attack and stroke) in patients taking it to prevent the recurrence of colorectal polyps. ${ }^{100}$ Furthermore, evidence suggests that indomethacin may interfere with fracture healing. ${ }^{141,142} \mathrm{~A}$ study in rats reported that indomethacin treatment diminished mechanical properties of femoral fracture calluses. ${ }^{141}$ This finding suggests that indomethacin treatment is problematic, particularly in patients with concomitant fracture. In addition, ibuprofen, a commonly prescribed NSAID, may worsen cognitive outcome after severe $\mathrm{TBI}$ in rats. ${ }^{143}$ Further, rats given a TBI and administered celecoxib, a COX-2 inhibitor often administered to $\mathrm{HO}$ patients, had worse motor performance. ${ }^{144}$ In some circumstances COX-1 inhibitors have been associated with an increased prevalence of gastrointestinal side effects such as bleeding and perforations. ${ }^{145,146}$ NSAIDs also have a limited therapeutic window and are only effective in the early stages of $\mathrm{HO}$ development, prior to the formation of ectopic bone (Fig. 2). Once bone deposition has occurred, NSAIDs are ineffective, hence surgical intervention remains the only option. Overall, despite the efficacy of NSAIDs in preventing/reducing ectopic bone formation, these findings support the notion that careful consideration must be taken before administering NSAIDs to polytrauma patients.

\section{Bisphosphonates}

Bisphosphonates are commonly used to treat bone disorders such as osteopenia, osteoporosis, and Paget's disease by reducing osteoclastic bone resorption. ${ }^{147}$ Nitrogen-containing bisphosphonates, such as 


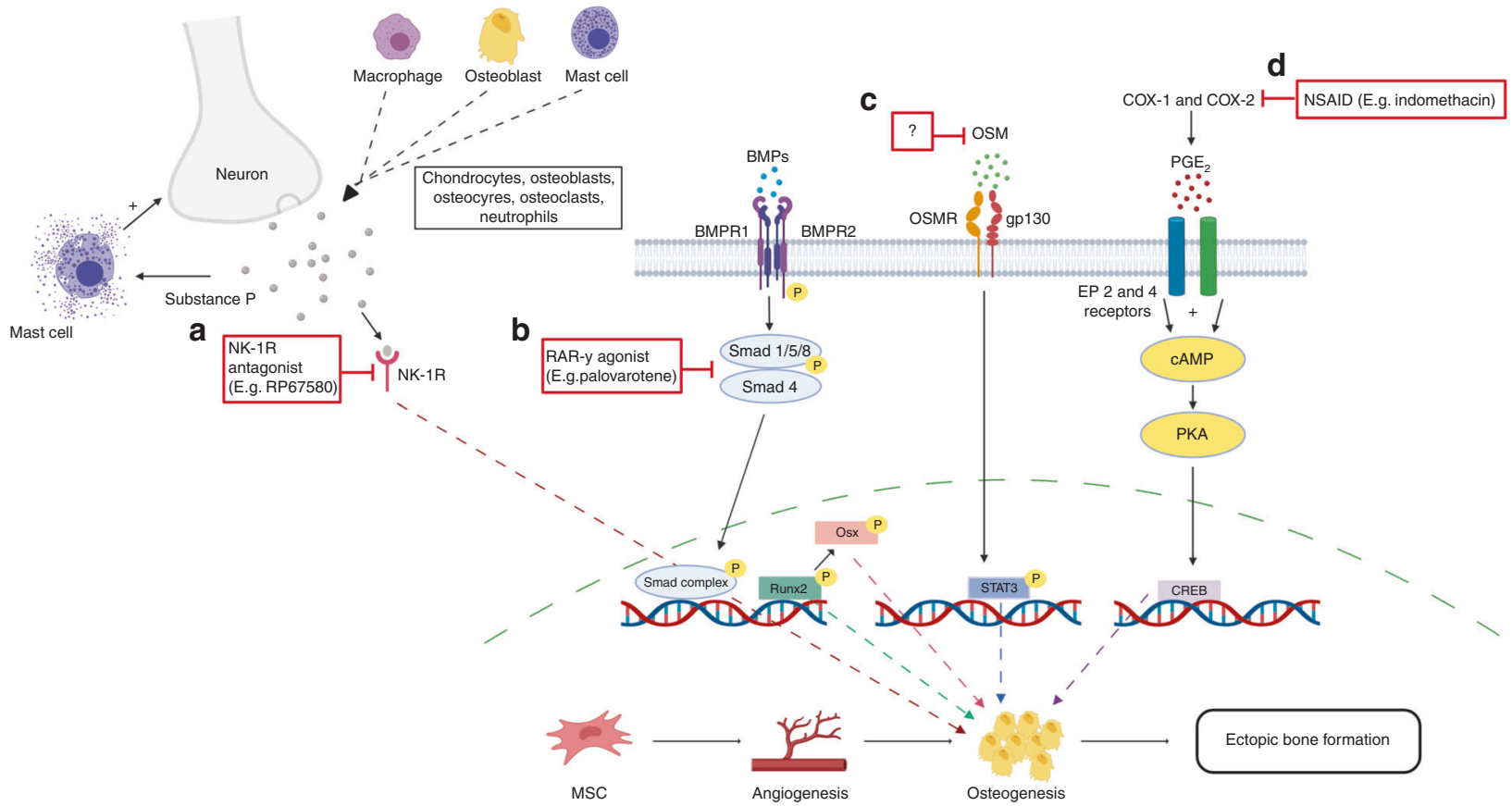

Fig. 3 Key pathways/mechanisms implicated in the development of NHO highlighting potential and existing therapeutic targets to mitigate NHO. a Substance P receptor (NK- ${ }_{1} \mathrm{R}$ ) antagonists (e.g. RP67580) have been found to reduce NHO volume in murine models. $\mathbf{b}$ Downstream of the BMP pathway, RAR- $\gamma$ agonists such as palovarotene have been reported to prevent early stages of NHO development by disrupting OPC differentiation, chondrogenesis and osteogenesis by downregulating mRNA expression of SOX-9 and RUNX2. c OSM is a potential therapeutic target and may serve as a biomarker for NHO. Blocking OSM has been found to reduce NHO likely by inhibiting downstream transcription factor, STAT3, which is known to trigger bone formation. d NSAID, indomethacin is currently the preferred prophylaxis for NHO/HO. It targets COX-1 and COX-2 non-selectively, inhibiting the production of prostaglandins and osteogenesis (created with BioRender.com)

risedronate, sodium etidronate, and alendronate, are often prescribed as prophylaxis due to their ability to effectively prevent mineralisation. ${ }^{148}$ In vitro, treatment of osteoblasts with nitrogencontaining bisphosphonates, pamidronate and alendronate, at doses of $10^{-4}-10^{-5} \mathrm{~mol} \cdot \mathrm{L}^{-1}$ (therapeutic doses range in humans is between $10^{-5}$ and $10^{-9} \mathrm{~mol} \cdot \mathrm{L}^{-1}$ ) results in osteoblastic apoptosis directly, and/or indirectly via osteoblast cell cycle arrest and cell proliferation inhibition. ${ }^{149,150}$ These findings were not observed when cells were treated with non-nitrogen-containing bisphosphonates. ${ }^{150}$ The use of nitrogen-containing etidronate in ectopic bone formation has been well documented. ${ }^{151-154}$ However, some studies do not recommend sodium etidronate as treatment for NHO. ${ }^{151,153}$ As bisphosphonates suppress bone resorption and accumulate in the body for an extended period of time, adverse effects associated with high doses include amassed bone microdamage which is frequently observed with old age, hence further contributing to increased skeletal fragility. ${ }^{155,156}$ In addition, due to the potentially negative impacts on skeletal fragility combined with the high cost of bisphosphonates, it would be beneficial to identify those patients who are at risk of developing $\mathrm{NHO}$, and treat only them with bisphosphonates. ${ }^{157}$ It is also unknown how bisphosphonates affect TBI and $\mathrm{SCl}$ outcomes, which should be considered in NHO patients.

Retinoic acid receptor agonist

Retinoic acid receptors (RAR) are mediators of skeletal development via the Smad complex, that plays an integral role in chondrogenesis. ${ }^{158}$ An RAR- ${ }_{\gamma}$ agonist, palovarotene, has shown to be effective in preventing the initial stages of NHO. ${ }^{159}$ The authors developed a model that mimics the injury combinations and bioburden that occurs in blast related combat injuries. ${ }^{159}$ Palovarotene significantly decreased $\mathrm{NHO}$ by inhibiting the expansion as well as differentiation of OPCs into chondrocytes. ${ }^{159}$ Further, palovarotene treatment was found to downregulate mRNA expression of chondrocytic
(SOX-9 and collagen2a1) and osteoblastic (OC, OPN, BMP-2, BMP-4, POU5FL and RUNX2) genes Fig. $3^{159-161}$

$\operatorname{RAR}_{-}{ }_{\gamma}$ activation, however has been shown to delay growth plate development. Therefore, several studies have warned that precautions should be taken when administering an RAR- ${ }_{\gamma}$ agonist to children. ${ }^{160,162}$ Whereas in adults, it was proposed that RARtreatment could be given intermittently, henceforth providing sufficient recovery time for the growth plate. ${ }^{160,162}$ Furthermore, as palovarotene has also been shown to inhibit fracture healing care should be taken when administering to patients with healing fractures. ${ }^{162-164}$ Nonetheless, activation of RAR- ${ }_{\gamma}$ still shows promising results as a novel therapeutic agent in preventing progression of $\mathrm{NHO}$.

\section{CONCLUSION}

The development of $\mathrm{NHO}$ is relatively common after $\mathrm{TBI}$ and $\mathrm{SCl}$, and typically occurs in the presence of concomitant significant peripheral musculoskeletal injuries. The majority of $\mathrm{NHO}$ cases are diagnosed following extensive mineralisation, at which stage patients are likely to experience considerable pain and disruption to daily functional activities. Current treatments are limited in effectiveness and not always suitable for $\mathrm{NHO}$ patients, and there are no reliable prognostic biomarkers to identify patients at high risk of developing $\mathrm{NHO}$ to guide preventative interventions. Fortunately, there are numerous promising avenues for future research to identify new underlying pathophysiological mechanisms related to $\mathrm{NHO}$, prognostic biomarkers, and prophylactic therapies that are suitable for complex trauma patients with CNS injuries. These future studies would benefit from a complementary translational approach that incorporates improved clinically relevant animal models in parallel with more rigorous clinical investigations. In doing so, there is the strong potential to develop biomarkers and prophylactic strategies to improve $\mathrm{NHO}$ patient outcomes. 


\section{ACKNOWLEDGEMENTS}

R.B. is supported by a grant from NINDS (NINDS RFA-NS-16-012) to T.O.B. and S.S. S.S. is supported by a fellowship from NHMRC.

\section{ADDITIONAL INFORMATION}

Competing interests: The authors declare no competing interests.

Publisher's note Springer Nature remains neutral with regard to jurisdictional claims in published maps and institutional affiliations.

\section{REFERENCES}

1. Garland, D. E. A clinical perspective on common forms of acquired heterotopic ossification. Clin. Orthop. Relat. Res. 263, 13-29 (1991).

2. Hoyt, B. W., Pavey, G. J., Potter, B. K. \& Forsberg, J. A. Heterotopic ossification and lessons learned from fifteen years at war: a review of therapy, novel research, and future directions for military and civilian orthopaedic trauma. Bone 109 3-11 (2018).

3. Citta-Pietrolungo, T. J., Alexander, M. A. \& Steg, N. L. Early detection of heterotopic ossification in young patients with traumatic brain injury. Arch. Phys. Med. Rehabil. 73, 258-262 (1992).

4. Mavrogenis, A. F., Soucacos, P. N. \& Papagelopoulos, P. J. Heterotopic ossification revisited. Orthopedics 34, 177 (2011).

5. Adiguzel, E. et al. Knee pain relief with genicular nerve blockage in two brain injured patients with heterotopic ossification. Brain Inj. 29, 1736-1739 (2015).

6. Brady, R. D., Shultz, S. R., McDonald, S. J. \& O'Brien, T. J. Neurological heterotopic ossification: current understanding and future directions. Bone 109, 35-42 (2018).

7. Davis, E. L., Davis, A. R., Gugala, Z. \& Olmsted-Davis, E. A. Is heterotopic ossification getting nervous?: the role of the peripheral nervous system in heterotopic ossification. Bone 109, 22-27 (2018).

8. Genêt, F. et al. Troublesome heterotopic ossification after central nervous system damage: a survey of 570 surgeries. PLoS ONE 6, e16632 (2011).

9. Maheswarappa, B., Nair, K., Taly, A., Shanthi, S. \& Murali, T. Heterotopic ossification at unusual site in traumatic brain injury. IJPMR 15, 34-37 (2004).

10. Cipriano, C. A., Pill, S. G. \& Keenan, M. A. Heterotopic ossification following traumatic brain injury and spinal cord injury. J. Am. Acad. Orthop. Surg. 17, 689-697 (2009)

11. Nauth, A. et al. Heterotopic ossification in orthopaedic trauma. J. Orthop. Trauma 26, 684-688 (2012)

12. Genêt, F. et al. Neurological heterotopic ossification following spinal cord injury is triggered by macrophage-mediated inflammation in muscle. J. Pathol. 236, 229-240 (2015)

13. Jodoin, $M$. et al. Investigating the incidence and magnitude of heterotopic ossification with and without joints involvement in patients with a limb fracture and mild traumatic brain injury. Bone Rep. 11, 100222 (2019).

14. Salga, M. et al. Sciatic nerve compression by neurogenic heterotopic ossification: use of CT to determine surgical indications. Skelet. Radiol. 44, 233-240 (2015).

15. Frost, R. B., Farrer, T. J., Primosch, M. \& Hedges, D. W. Prevalence of traumatic brain injury in the general adult population: a meta-analysis. Neuroepidemiology 40, 154-159 (2013).

16. Ranganathan, K. et al. Role of gender in burn-induced heterotopic ossification and mesenchymal cell osteogenic differentiation. Plast. Reconstr. Surg. 135, 1631-1641 (2015).

17. Larson, J. M. et al. Increased prevalence of HLA-B27 in patients with ectopic ossification following traumatic spinal cord injury. Rheumatology 20, 193-197 (1981).

18. Hunter, T., Dubo, H., Hildahl, C., Smith, N. \& Schroeder, M. Histocompatibility antigens in patients with spinal cord injury or cerebral damage complicated by heterotopic ossification. Rheumatology 19, 97-99 (1980).

19. Sakellariou, V., Grigoriou, E., Mavrogenis, A., Soucacos, P. \& Papagelopoulos, P. Heterotopic ossification following traumatic brain injury and spinal cord injury: insight into the etiology and pathophysiology. J. Musculoskelet. Neuronal Interact. 12, 230-240 (2012).

20. Dizdar, D. et al. Risk factors for developing heterotopic ossification in patients with traumatic brain injury. Brain Inj. 27, 807-811 (2013).

21. Simonsen, L. L., Sonne-Holm, S., Krasheninnikoff, M. \& Engberg, A. W. Symptomatic heterotopic ossification after very severe traumatic brain injury in 114 patients: incidence and risk factors. Injury 38, 1146-1150 (2007).

22. Van Kampen, P., Martina, J., Vos, P., Hoedemaekers, C. \& Hendricks, H. Potential risk factors for developing heterotopic ossification in patients with severe traumatic brain injury. J. Head Trauma Rehabil. 26, 384-391 (2011).
23. Forsberg, J. A. \& Potter, B. K. Heterotopic Ossification in Wartime Wounds. J. Surg. Orthop. Adv. Spring. 19, 54-61 (2010).

24. Taber, K. H., Warden, D. L. \& Hurley, R. A. Blast-related traumatic brain injury: what is known?. J. Neuropsychiatry Clin. Neurosci. 18, 141-145 (2006).

25. Rosenfeld, J. V. et al. Blast-related traumatic brain injury. Lancet Neurol. 12 882-893 (2013)

26. Forsberg, J. A. et al. Heterotopic ossification in high-energy wartime extremity injuries: prevalence and risk factors. J. Bone Jt. Surg. Am. 91, 1084-1091 (2009).

27. Clark, M. E., Scholten, J. D., Walker, R. L. \& Gironda, R. J. Assessment and treatment of pain associated with combat-related polytrauma. Pain Med. 10, 456-469 (2009).

28. Alizadeh, A., Dyck, S. M. \& Karimi-Abdolrezaee, S. Traumatic spinal cord injury: an overview of pathophysiology, models and acute injury mechanisms. Front. Neurol. 10, 282 (2019).

29. Smith, E., Comiskey, C. \& Carroll, A. Prevalence of and risk factors for osteoporosis in adults with acquired brain injury. Ir. J. Med. Sci. 185, 473-481 (2016).

30. Maas, A. I., Stocchetti, N. \& Bullock, R. Moderate and severe traumatic brain injury in adults. Lancet Neurol. 7, 728-741 (2008).

31. Blennow, K., Hardy, J. \& Zetterberg, H. The neuropathology and neurobiology of traumatic brain injury. Neuron 76, 886-899 (2012).

32. Alves, J. L. Blood-brain barrier and traumatic brain injury. J. Neurosci. Res. 92, 141-147 (2014).

33. Stamatovic, S. M., Keep, R. F. \& Andjelkovic, A. V. Brain endothelial cell-cell junctions: how to "open" the blood brain barrier. Curr. Neuropharmacol. 6, 179-192 (2008).

34. Wilson, E. H., Weninger, W. \& Hunter, C. A. Trafficking of immune cells in the central nervous system. J. Clin. Investig. 120, 1368-1379 (2010).

35. Wolburg, H., Wolburg-Buchholz, K. \& Engelhardt, B. Involvement of tight junctions during transendothelial migration of mononuclear cells in experimental autoimmune encephalomyelitis. Ernst Schering Res. Found. Workshop. 47,17-38 (2004).

36. Shlosberg, D., Benifla, M., Kaufer, D. \& Friedman, A. Blood-brain barrier breakdown as a therapeutic target in traumatic brain injury. Nat. Rev. Neurol. 6 393-403 (2010).

37. Bidner, S. M., Rubins, I. M., Desjardins, J. V., Zukor, D. J. \& Goltzman, D. Evidence for a humoral mechanism for enhanced osteogenesis after head injury. J. Bone Jt. Surg. Am. 72, 1144-1149 (1990).

38. Gautschi, O. P. et al. Osteoinductive effect of cerebrospinal fluid from braininjured patients. J. Neurotrauma 24, 154-162 (2007).

39. Quinn, M. \& Agha, A. Post-traumatic hypopituitarism—who should be screened, when, and how? Front. Endocrinol. 9, 8 (2018).

40. Tan, C. L. et al. The screening and management of pituitary dysfunction following traumatic brain injury in adults: British Neurotrauma Group guidance. J. Neurol. Neurosurg. Psychiatry 88, 971-981 (2017).

41. Silva, B. C. \& Bilezikian, J. P. Parathyroid hormone: anabolic and catabolic actions on the skeleton. Curr. Opin. Pharmacol. 22, 41-50 (2015).

42. Lindsey, R. C. \& Mohan, S. Skeletal effects of growth hormone and insulin-like growth factor-I therapy. Mol. Cell. Endocrinol. 432, 44-55 (2016).

43. Cadosch, D. et al. Humoral factors enhance fracture-healing and callus formation in patients with traumatic brain injury. J. Bone Jt. Surg. Am. 91, 282-288 (2009).

44. Giannoudis, P. V. et al. Accelerated bone healing and excessive callus formation in patients with femoral fracture and head injury. Injury 37, S18-S24 (2006).

45. Perkins, R. \& Skirving, A. Callus formation and the rate of healing of femoral fractures in patients with head injuries. J. Bone Jt. Surg. Br. 69, 521-524 (1987).

46. Locher, R. J. et al. Traumatic brain injury and bone healing: radiographic and biomechanical analyses of bone formation and stability in a combined murine trauma model. J. Musculoskelet. Neuronal Interact. 15, 309-315 (2015).

47. Tsitsilonis, S. et al. The effect of traumatic brain injury on bone healing: an experimental study in a novel in vivo animal model. Injury 46, 661-665 (2015).

48. Wang, L. et al. Effect of leptin on bone metabolism in rat model of traumatic brain injury and femoral fracture. Chin. J. Traumatol. 14, 7-13 (2011).

49. Wei, Y., Wang, L., Clark, J. C., Dass, C. R. \& Choong, P. F. Elevated leptin expression in a rat model of fracture and traumatic brain injury. J. Pharm. Pharmacol. 60 1667-1672 (2008)

50. Liu, X. et al. SDF-1 promotes endochondral bone repair during fracture healing at the traumatic brain injury condition. PloS ONE 8, e54077 (2013).

51. Brady, R. D. et al. Closed head experimental traumatic brain injury increases size and bone volume of callus in mice with concomitant tibial fracture. Sci. Rep. 6 , 34491 (2016).

52. Wang, L. et al. The effects of spinal cord injury on bone healing in patients with femoral fractures. J. Spinal Cord Med. 37, 414-419 (2014).

53. Morioka, K. et al. Differential fracture response to traumatic brain injury suggests dominance of neuroinflammatory response in polytrauma. Sci. Rep. 9, 1-16 (2019). 
54. Brady, R. D. et al. Experimental traumatic brain injury induces bone loss in rats. J. Neurotrauma 33, 2154-2160 (2016).

55. Brady, R. et al. Sodium selenate treatment mitigates reduction of bone volume following traumatic brain injury in rats. J. Musculoskelet. Neuronal Interact. 16, 369-376 (2016).

56. Kaplan, F. S., Glaser, D. L., Hebela, N. \& Shore, E. M. Heterotopic ossification. J. Am. Acad. Orthop. Surg. 12, 116-125 (2004).

57. Shimono, K., Uchibe, K., Kuboki, T. \& Iwamoto, M. The pathophysiology of heterotopic ossification: current treatment considerations in dentistry. Jpn. Dent. Sci. Rev. 50, 1-8 (2014).

58. Edwards, D. S. \& Clasper, J. Heterotopic ossification: a systematic review. J. $R$. Army Med. Corps 161, 315-321 (2015).

59. Shore, E. M. \& Kaplan, F. S. Inherited human diseases of heterotopic bone formation. Nat. Rev. Rheumatol. 6, 518-527 (2010).

60 . Kan, $C$. et al. Conserved signaling pathways underlying heterotopic ossification. Bone 109, 43-48 (2018)

61. Hwang, $C$. et al. Mesenchymal VEGFA induces aberrant differentiation in heterotopic ossification. Bone Res. 7, 1-17 (2019).

62. Robins, J. C. et al. Hypoxia induces chondrocyte-specific gene expression in mesenchymal cells in association with transcriptional activation of Sox9. Bone 37, 313-322 (2005).

63. Stegen, S., van Gastel, N. \& Carmeliet, G. Bringing new life to damaged bone: the importance of angiogenesis in bone repair and regeneration. Bone 70, 19-27 (2015).

64. Qureshi, A. T. et al. Early characterization of blast-related heterotopic ossification in a rat model. Clin. Orthop. Relat. Res. 473, 2831-2839 (2015).

65. Agarwal, S. et al. Diminished chondrogenesis and enhanced osteoclastogenesis in leptin-deficient diabetic mice (ob/ob) impair pathologic, trauma-induced heterotopic ossification. Stem Cells Dev. 24, 2864-2872 (2015).

66. Allen, M. R. \& Burr, D. B. in Basic and Applied Bone Biology (eds David, B. Burr \& Matthew, R. Allen) 75-90 (Academic Press, 2014).

67. Chalmers, J., Gray, D. \& Rush, J. Observations on the induction of bone in soft tissues. J. Bone Jt. Surg. Br. 57, 36-45 (1975).

68. Davies, O. G., Grover, L. M., Eisenstein, N., Lewis, M. P. \& Liu, Y. Identifying the cellular mechanisms leading to heterotopic ossification. Calcif. Tissue Int. 97, 432-444 (2015).

69. Lees-Shepard, J. B. \& Goldhamer, D. J. Stem cells and heterotopic ossification: lessons from animal models. Bone 109, 178-186 (2018).

70. Foley, K. L., Hebela, N., Keenan, M. A. \& Pignolo, R. J. Histopathology of periarticular non-hereditary heterotopic ossification. Bone 109, 65-70 (2018).

71. Dey, D. et al. The traumatic bone: trauma-induced heterotopic ossification. Transl. Res. 186, 95-111 (2017).

72. Meyers, C. et al. Heterotopic ossification: a comprehensive review. JBMR Plus $\mathbf{3}$, e10172 (2019)

73. Łęgosz, P., Drela, K., Pulik, Ł., Sarzyńska, S. \& Małdyk, P. Challenges of heterotopic ossification-molecular background and current treatment strategies. Clin. Exp. Pharmacol. Physiol. 45, 1229-1235 (2018).

74. Ranganathan, K. et al. Heterotopic ossification: basic-science principles and clinical correlates. J. Bone Jt. Surg. Br. 97, 1101-1111 (2015).

75. Xu, R., Hu, J., Zhou, X. \& Yang, Y. Heterotopic ossification: mechanistic insights and clinical challenges. Bone 109, 134-142 (2018).

76. Sorkin, M. et al. Regulation of heterotopic ossification by monocytes in a mouse model of aberrant wound healing. Nat. Commun. 11, 1-17 (2020)

77. Tseng, H. W. et al. Neurogenic heterotopic ossifications develop independently of granulocyte-colony stimulating factor and neutrophils. J. Bone Miner. Res. 1-10 (2020).

78. Torossian, F. et al. Macrophage-derived oncostatin $M$ contributes to human and mouse neurogenic heterotopic ossifications. JCl Insight 2, e96034 (2017).

79. Suda, R. K. et al. Circulating osteogenic precursor cells in heterotopic bone formation. Stem Cells 27, 2209-2219 (2009).

80. Sims, N. A. \& Quinn, J. M. Osteoimmunology: oncostatin M as a pleiotropic regulator of bone formation and resorption in health and disease. Bonekey Rep. 3, 527 (2014)

81. Brady, R. D. et al. A novel rat model of heterotopic ossification after polytrauma with traumatic brain injury. Bone 133, 115263 (2020)

82. Hausmann, O. B. Post-traumatic inflammation following spinal cord injury. Spinal Cord 41, 369-378 (2003).

83. Chodobski, A., Zink, B. J. \& Szmydynger-Chodobska, J. Blood-brain barrier pathophysiology in traumatic brain injury. Transl. Stroke Res. 2, $492-516$ (2011).

84. Werner, C. \& Engelhard, K. Pathophysiology of traumatic brain injury. BJA Br. J. Anaesth. 99, 4-9 (2007).

85. Nimmo, A. et al. Neurogenic inflammation is associated with development of edema and functional deficits following traumatic brain injury in rats. Neuropeptides 38, 40-47 (2004).

86. Bajwa, N. M., Kesavan, C. \& Mohan, S. Long-term consequences of traumatic brain injury in bone metabolism. Front. Neurol. 9, 115 (2018).
87. Payan, D. G. Neuropeptides and inflammation: the role of substance P. Annu. Rev. Med. 40, 341-352 (1989).

88. Azuma, H., Kido, Ji, Ikedo, D., Kataoka, M. \& Nagata, T. Substance P enhances the inhibition of osteoblastic cell differentiation induced by lipopolysaccharide from porphyromonas gingivalis. J. Periodontol. 75, 974-981 (2004).

89. Kan, L. et al. Substance $P$ signaling mediates BMP-dependent heterotopic ossification. J. Cell. Biochem. 112, 2759-2772 (2011).

90. Salisbury, E. et al. Sensory nerve induced inflammation contributes to heterotopic ossification. J. Cell. Biochem. 112, 2748-2758 (2011).

91. Goto, T. et al. Substance P stimulates late-stage rat osteoblastic bone formation through neurokinin-1 receptors. Neuropeptides 41, 25-31 (2007).

92. Sharma, H. S., Nyberg, F., Olsson, Y. \& Dey, P. K. Alteration of substance P after trauma to the spinal cord: an experimental study in the rat. Neuroscience $\mathbf{3 8}$, 205-212 (1990).

93. Donkin, J. J., Turner, R. J., Hassan, I. \& Vink, R. Substance P in traumatic brain injury. Prog. Brain Res. 161, 97-109 (2007).

94. Medici, D. \& Olsen, B. R. The role of endothelial-mesenchymal transition in heterotopic ossification. J. Bone Miner. Res. 27, 1619-1622 (2012).

95. Reichel, L. M., Salisbury, E., Moustoukas, M. J., Davis, A. R. \& Olmsted-Davis, E. Molecular mechanisms of heterotopic ossification. J. Hand Surg. 39, 563-566 (2014).

96. Salisbury, E., Sonnet, C., Heggeness, M., Davis, A. R. \& Olmsted-Davis, E. Heterotopic ossification has some nerve. Crit. Rev. Eukaryot. Gene Expr. 20, 313-324 (2010).

97. Pearn, M. L. et al. Pathophysiology associated with traumatic brain injury: current treatments and potential novel therapeutics. Cell. Mol. Neurobiol. 37, 571-585 (2017).

98. Vink, R. \& van den Heuvel, C. Substance P antagonists as a therapeutic approach to improving outcome following traumatic brain injury. Neurotherapeutics 7 , 74-80 (2010).

99. González-Hernández, A. et al. Heteroreceptors modulating CGRP release at neurovascular junction: potential therapeutic implications on some vascularrelated diseases. Biomed Res. Int. 2016, 2056786 (2016).

100. Irie, K., Hara-Irie, F., Ozawa, H. \& Yajima, T. Calcitonin gene-related peptide (CGRP)-containing nerve fibers in bone tissue and their involvement in bone remodeling. Microsc. Res. Tech. 58, 85-90 (2002).

101. Sang, X., Wang, Z., Shi, P., Li, Y. \& Cheng, L. CGRP accelerates the pathogenesis of neurological heterotopic ossification following spinal cord injury. Artif. Cells Nanomed. Biotechnol. 47, 2569-2574 (2019).

102. Song, Y. et al. Increased levels of calcitonin gene-related peptide in serum accelerate fracture healing following traumatic brain injury. Mol. Med. Rep. 5, 432-438 (2012).

103. Song, Y. et al. The role of the hippocampus and the function of calcitonin generelated peptide in the mechanism of traumatic brain injury accelerating fracture-healing. Eur. Rev. Med. Pharmacol. Sci. 21, 1522-1531 (2017).

104. Zhang, D. et al. The influence of brain injury or peripheral nerve injury on calcitonin gene-related peptide concentration variation and fractures healing process. Artif. Cells Blood Substit. Biotechnol. 37, 85-91 (2009).

105. Sofroniew, M. V., Howe, C. L. \& Mobley, W. C. Nerve growth factor signaling, neuroprotection, and neural repair. Annu. Rev. Neurosci. 24, 1217-1281 (2001).

106. Tomlinson, RyanE. et al. NGF-TrkA signaling by sensory nerves coordinates the vascularization and ossification of developing endochondral bone. Cell Rep. 16, 2723-2735 (2016).

107. Grills, B. L. \& Schuijers, J. A. Immunohistochemical localization of nerve growth factor in fractured and unfractured rat bone. Acta Orthop. Scand. 69, 415-419 (1998).

108. Li, X., Sun, D., Li, Y. \& Wu, X. Neurotrophin-3 improves fracture healing in rats. Eur. Rev. Med. Pharmacol. Sci. 22, 2439-2446 (2018).

109. Asaumi, K., Nakanishi, T., Asahara, H., Inoue, H. \& Takigawa, M. Expression of neurotrophins and their receptors (TRK) during fracture healing. Bone 26, 625-633 (2000).

110. Zhang, J. et al. Macrophage-derived neurotrophin-3 promotes heterotopic ossification in rats. Lab. Investig. 100, 762-776 (2020).

111. Corr, A., Smith, J. \& Baldock, P. Neuronal control of bone remodeling. Toxicol. Pathol. 45, 894-903 (2017)

112. Otto, E. et al. Crosstalk of brain and bone-clinical observations and their molecular bases. Int. J. Mol. Sci. 21, 4946 (2020).

113. Takeda, S. et al. Leptin regulates bone formation via the sympathetic nervous system. Cell 111, 305-317 (2002).

114. Chao, S. T., Joyce, M. J. \& Suh, J. H. Treatment of heterotopic ossification. Orthopedics 30, 457-464 (2007).

115. Shehab, D., Elgazzar, A. H. \& Collier, B. D. Heterotopic ossification. J. Nucl. Med. 43, 346-353 (2002)

116. Ebinger, T., Roesch, M., Kiefer, H., Kinzl, L. \& Schulte, M. Influence of etiology in heterotopic bone formation of the hip. J. Trauma Acute Care Surg. 48, 1058-1062 (2000). 
117. Subbarao, J. V. \& Garrison, S. J. Heterotopic ossification: diagnosis and management current concepts and controversies. J. Spinal Cord. Med. 22, 273-283 (1999).

118. Sullivan, M., Torres, S., Mehta, S. \& Ahn, J. Heterotopic ossification after central nervous system trauma: a current review. Bone Jt. Res. 2, 51-57 (2013).

119. Almangour, W. et al. Recurrence of heterotopic ossification after removal in patients with traumatic brain injury: a systematic review. Ann. Phys. Rehabil. Med. 59, 263-269 (2016)

120. Genet, F. et al. Impact of the operative delay and the degree of neurologic sequelae on recurrence of excised heterotopic ossification in patients with traumatic brain injury. J. Head Trauma Rehabil. 27, 443-448 (2012).

121. Genet, F. et al. Beliefs relating to recurrence of heterotopic ossification following excision in patients with spinal cord injury: a review. Spinal Cord 53, 340-344 (2015).

122. Genêt, F. et al. Impact of late surgical intervention on heterotopic ossification of the hip after traumatic neurological injury. J. Bone Jt. Surg. Br. 91, 1493-1498 (2009).

123. Agarwal, S. et al. Surgical excision of heterotopic ossification leads to reemergence of mesenchymal stem cell populations responsible for recurrence. Stem Cells Transl. Med. 6, 799-806 (2017).

124. Melamed, E. et al. Brain injury-related heterotopic bone formation: treatment strategy and results. Am. J. Phys. Med. Rehabil. 81, 670-674 (2002).

125. van Kuijk, A. A., Geurts, A. C. H. \& van Kuppevelt, H. J. M. Neurogenic heterotopic ossification in spinal cord injury. Spinal Cord 40, 313-326 (2002)

126. Pavey, G. J. et al. What risk factors predict recurrence of heterotopic ossification after excision in combat-related amputations? Clin. Orthop. Relat. Res. 473, 2814-2824 (2015).

127. Barfield, W. R., Holmes, R. E. \& Hartsock, L. A. Heterotopic ossification in trauma. Orthop. Clin. 48, 35-46 (2017).

128. Potter, B. K., Burns, T. C., Lacap, A. P., Granville, R. R. \& Gajewski, D. A. Heterotopic ossification following traumatic and combat-related amputations: prevalence, risk factors, and preliminary results of excision. J. Bone Jt. Surg. Am. 89, 476-486 (2007).

129. Tsionos, I., Leclercq, C. \& Rochet, J. M. Heterotopic ossification of the elbow in patients with burns. J. Bone Jt. Surg. Br. 86-B, 396-403 (2004).

130. Pohl, F. et al. Radiation-induced suppression of the Bmp2 signal transduction pathway in the pluripotent mesenchymal cell line $\mathrm{C} 2 \mathrm{C} 12$ : an in vitro model for prevention of heterotopic ossification by radiotherapy. Radiat. Res. 159, 345-350 (2003).

131. Szymczyk, K., Shapiro, I. \& Adams, C. S. lonizing radiation sensitizes bone cells to apoptosis. Bone 34, 148-156 (2004).

132. Craven, P. L. \& URIsT, M. R. Osteogenesis by radioisotope labelled cell populations in implants of bone matrix under the influence of ionizing radiation. Clin. Orthop. Relat. Res. 76, 231-243 (1971).

133. Sautter-Bihl, M., Liebermeister, E. \& Nanassy, A. Radiotherapy as a local treatment option for heterotopic ossifications in patients with spinal cord injury. Spinal Cord 38, 33-36 (2000).

134. Hamid, N. et al. Radiation therapy for heterotopic ossification prophylaxis acutely after elbow trauma: a prospective randomized study. J. Bone Jt. Surg. Am. 92, 2032-2038 (2010).

135. Burd, T. A., Lowry, K. J. \& Anglen, J. O. Indomethacin compared with localized irradiation for the prevention of heterotopic ossification following surgical treatment of acetabular fractures. J. Bone Jt. Surg. Am. 83, 1783-1788 (2001).

136. Haubner, F., Ohmann, E., Pohl, F., Strutz, J. \& Gassner, H. G. Wound healing after radiation therapy: review of the literature. Radiat. Oncol. 7, 162 (2012).

137. Farris, M. K., Chowdhry, V. K., Lemke, S., Kilpatrick, M. \& Lacombe, M. Osteosarcoma following single fraction radiation prophylaxis for heterotopic ossification. Radiat. Oncol. 7, 1-6 (2012).

138. Banovac, K., Williams, J. M., Patrick, L. D. \& Haniff, Y. M. Prevention of heterotopic ossification after spinal cord injury with indomethacin. Spinal Cord 39, 370-374 (2001).

139. DiCesare, P. E., Nimni, M. E., Peng, L., Yazdi, M. \& Cheung, D. T. Effects of indomethacin on demineralized bone-induced heterotopic ossification in the rat. J. Orthop. Res. 9, 855-861 (1991).

140. Sibbald, B. Drug Regulation: Rofecoxib (Vioxx) voluntarily withdrawn from market. Can. Med. Assoc. J. 171, 1027-1028 (2004).

141. Rø, J., Sudmann, E. \& Marton, P. F. Effect of indomethacin on fracture healing in rats. Acta Orthop. Scand. 47, 588-599 (1976).

142. Baird, E. O. \& Kang, Q. K. Prophylaxis of heterotopic ossification-an updated review. J. Orthop. Surg. Res. 4, 12 (2009).

143. Browne, K. D., Iwata, A., Putt, M. E. \& Smith, D. H. Chronic ibuprofen administration worsens cognitive outcome following traumatic brain injury in rats. Exp. Neurol. 201, 301-307 (2006).

144. Dash, P. K., Mach, S. A. \& Moore, A. N. Regional expression and role of cyclooxygenase-2 following experimental traumatic brain injury. J. Neurotrauma 17, 69-81 (2000).
145. Suleyman, H., Demircan, B. \& Karagoz, Y. Anti-inflammatory and side effects of cyclo-oxygenase inhibitors. Pharmacol. Rep. 59, 247-258 (2007).

146. Green, G. A. Understanding NSAIDs: from aspirin to COX-2. Clin. Cornerstone 3 , 50-59 (2001).

147. Drake, M. T., Clarke, B. L. \& Khosla, S. Bisphosphonates: mechanism of action and role in clinical practice. Mayo Clin. Proc. 83, 1032-1045 (2008).

148. Russell, R. G. G. Bisphosphonates: mode of action and pharmacology. Pediatrics 119, S150-S162 (2007).

149. Manzano-Moreno, F. J., Ramos-Torrecillas, J., De Luna-Bertos, E., Ruiz, C. \& GarcíaMartínez, O. High doses of bisphosphonates reduce osteoblast-like cell proliferation by arresting the cell cycle and inducing apoptosis. J. Cranio-Maxillofac. Surg. 43, 396-401 (2015).

150. Idris, A. I., Rojas, J., Greig, I. R., van't Hof, R. J. \& Ralston, S. H. Aminobisphosphonates cause osteoblast apoptosis and inhibit bone nodule formation in vitro. Calcif. Tissue Int. 82, 191-201 (2008).

151. Garland, D. E., Alday, B., Venos, K. G. \& Vogt, J. C. Diphosphonate treatment for heterotopic ossification in spinal cord injury patients. Clin. Orthop. Relat. Res. 176, 197-200 (1983).

152. Banovac, K., Gonzalez, F., Wade, N. \& Bowker, J. J. Intravenous disodium etidronate therapy in spinal cord injury patients with heterotopic ossification. Spinal Cord 31, 660-666 (1993).

153. Banovac, K., Gonzalez, F. \& Renfree, K. J. Treatment of heterotopic ossification after spinal cord injury. J. Spinal Cord Med. 20, 60-65 (1997).

154. Banovac, K. The effect of etidronate on late development of heterotopic ossification after spinal cord injury. J. Spinal Cord Med. 23, 40-44 (2000).

155. Mashiba, T. et al. Suppressed bone turnover by bisphosphonates increases microdamage accumulation and reduces some biomechanical properties in dog rib. J. Bone Miner. Res. 15, 613-620 (2000).

156. Burr, D. B. et al. Bone microdamage and skeletal fragility in osteoporotic and stress fractures. J. Bone Miner. Res. 12, 6-15 (1997).

157. Vasileiadis, G. et al. Prevention of heterotopic ossification in cases of hypertrophic osteoarthritis submitted to total hip arthroplasty. Etidronate or Indomethacin. J. Musculoskelet. Neuronal Interact. 10, 159-165 (2010).

158. Williams, J. A. et al. Retinoic acid receptors are required for skeletal growth, matrix homeostasis and growth plate function in postnatal mouse. Dev. Biol. 328, 315-327 (2009).

159. Pavey, G. J. et al. Targeted stimulation of retinoic acid receptor- $\gamma$ mitigates the formation of heterotopic ossification in an established blast-related traumatic injury model. Bone 90, 159-167 (2016).

160. Shimono, K. et al. Potent inhibition of heterotopic ossification by nuclear retinoic acid receptor- $\gamma$ agonists. Nat. Med. 17, 454-460 (2011).

161. Yasuhara, R. et al. Wnt/ $\beta$-catenin and retinoic acid receptor signaling pathways interact to regulate chondrocyte function and matrix turnover. J. Biol. Chem. 285, 317-327 (2010).

162. De Luca, F. et al. Retinoic acid is a potent regulator of growth plate chondrogenesis. Endocrinology 141, 346-353 (2000).

163. Shimono, K. et al. Potent inhibition of heterotopic ossification by nuclear retinoic acid receptor-gamma agonists. Nat. Med. 17, 454-460 (2011).

164. Pavey, G. J. et al. Targeted stimulation of retinoic acid receptor-gamma mitigates the formation of heterotopic ossification in an established blast-related traumatic injury model. Bone 90, 159-167 (2016).

165. Reznik, J. et al. Prevalence and risk-factors of neurogenic heterotopic ossification in traumatic spinal cord and traumatic brain injured patients admitted to specialised units in Australia. J. Musculoskelet. Neuronal Interact. 14, 19-28 (2014).

166. Rigaux, P. et al. Study of serum factors potentially involved in the pathogenesis of heterotopic bone formation after severe brain injury. Jt. Bone Spine 72, 146-149 (2005).

167. Hurvitz, E. A., Mandac, B. R., Davidoff, G., Johnson, J. H. \& Nelson, V. S. Risk factors for heterotopic ossification in children and adolescents with severe traumatic brain injury. Arch. Phys. Med. Rehabil. 73, 459-462 (1992).

168. Hendricks, H. T., Geurts, A., van Ginneken, B. C., Heeren, A. J. \& Vos, P. E. Brain injury severity and autonomic dysregulation accurately predict heterotopic ossification in patients with traumatic brain injury. Clin. Rehabil. 21, 545-553 (2007).

169. Seipel, R. et al. Neurogenic heterotopic ossification: epidemiology and morphology on conventional radiographs in an early neurological rehabilitation population. Skelet. Radiol. 41, 61-66 (2012).

170. Singh, R. S., Craig, M. C., Katholi, C. R., Jackson, A. B. \& Mountz, J. M. The predictive value of creatine phosphokinase and alkaline phosphatase in identification of heterotopic ossification in patients after spinal cord injury. Arch. Phys. Med. Rehabil. 84, 1584-1588 (2003).

171. Wittenberg, R., Peschke, U. \& Botel, U. Heterotopic ossification after spinal cord injury. Epidemiology and risk factors. J. Bone Jt. Surg. Br. 74, 215-218 (1992).

172. Bravo-Payno, P., Esclarin, A., Arzoz, T., Arroyo, O. \& Labarta, C. Incidence and risk factors in the appearance of heterotopic ossification in spinal cord injury. Spinal Cord 30, 740-745 (1992). 
173. Orzel, J. A. \& Rudd, T. G. Heterotopic bone formation: clinical, laboratory, and imaging correlation. J. Nucl. Med. 26, 125-132 (1985).

174. Meiners, T., Abel, R., Böhm, V. \& Gerner, H. Resection of heterotopic ossification of the hip in spinal cord injured patients. Spinal Cord 35, 443-445 (1997).

175. Hunt, J. L., Arnoldo, B. D., Kowalske, K., Helm, P. \& Purdue, G. F. Heterotopic ossification revisited: a 21-year surgical experience. J. Burn Care Res. 27, 535-540 (2006).

176. Stein, D. A. et al. Prevention of heterotopic ossification at the elbow following trauma using radiation therapy. Bull. Hosp. Jt. Dis. N.Y. 61, 151-154 (2003).

177. Müseler, A. et al. In-hospital outcomes following single-dose radiation therapy in the treatment of heterotopic ossification of the hip following spinal cord injury-an analysis of 444 cases. Spinal Cord 55, 244-246 (2017).

178. Cipriano, C., Pill, S. G., Rosenstock, J. \& Keenan, M. A. Radiation therapy for preventing recurrence of neurogenic heterotopic ossification. Orthopedics 32 , 685-689 (2009).

179. Banovac, K., Williams, J., Patrick, L. \& Levi, A. Prevention of heterotopic ossification after spinal cord injury with COX-2 selective inhibitor (rofecoxib). Spinal Cord 42, 707-710 (2004).

180. Romanò, C. L., Duci, D., Romanò, D., Mazza, M. \& Meani, E. Celecoxib versus indomethacin in the prevention of heterotopic ossification after total hip arthroplasty. J. Arthroplast. 19, 14-18 (2004).

181. Schmidt, S. A. et al. The use of indomethacin to prevent the formation of heterotopic bone after total hip replacement. A randomized, double-blind clinical trial. J. Bone Jt. Surg. Am. 70, 834-838 (1988).
182. Bedi, A. et al. The incidence of heterotopic ossification after hip arthroscopy. Am. J. Sports Med. 40, 854-863 (2012).

183. Beckmann, J. T. et al. Effect of naproxen prophylaxis on heterotopic ossification following hip arthroscopy: a double-blind randomized placebo-controlled trial. J. Bone Jt. Surg. Am. 97, 2032-2037 (2015).

184. Neal, B. C. et al. No effect of low-dose aspirin for the prevention of heterotopic bone formation after total hip replacement: a randomized trial of 2649 patients. Acta Orthop. Scand. 71, 129-134 (2000).

185. Schuetz, P., Mueller, B., Christ-Crain, M., Dick, W. \& Haas, H. Aminobisphosphonates in heterotopic ossification: first experience in five consecutive cases. Spinal Cord 43, 604-610 (2005).

(i) Open Access This article is licensed under a Creative Commons Attribution 4.0 International License, which permits use, sharing, adaptation, distribution and reproduction in any medium or format, as long as you give appropriate credit to the original author(s) and the source, provide a link to the Creative Commons license, and indicate if changes were made. The images or other third party material in this article are included in the article's Creative Commons license, unless indicated otherwise in a credit line to the material. If material is not included in the article's Creative Commons license and your intended use is not permitted by statutory regulation or exceeds the permitted use, you will need to obtain permission directly from the copyright holder. To view a copy of this license, visit http://creativecommons. org/licenses/by/4.0/.

(c) The Author(s) 2020 